\title{
Seasonal variation in chaetognath and parasite species assemblages along the northeastern coast of the Yucatan Peninsula
}

\author{
Horacio Lozano-Cobo' ${ }^{1}$, María del Carmen Gómez del Prado-Rosas ${ }^{2}$, \\ Laura Sánchez-Velasco' ${ }^{1}$, Jaime Gómez-Gutiérrez ${ }^{1, *}$
}

${ }^{1}$ Instituto Politécnico Nacional, Centro Interdisciplinario de Ciencias Marinas, Departamento de Plancton y Ecología Marina, Av. IPN s/n, La Paz, BCS 23096, Mexico

${ }^{2}$ Laboratorio de Parasitología, Departamento Académico de Biología Marina, Universidad Autónoma de Baja California Sur, Apdo. Postal 19-B, La Paz, BCS 23080, Mexico

\begin{abstract}
Chaetognaths are abundant carnivores with broad distributions that are intermediate hosts of trophically transmitted parasites. Monthly variations in chaetognath and parasite species distributions, abundance, prevalence, and intensity related to seasonal environmental changes were recorded in 2004 and 2005 in Laguna Nichupté, a coral reef, and the adjoining continental shelf of Quintana Roo, Mexico. Of 12 chaetognath species plus Sagitta spp., only 5 (Ferosagitta hispida, Flaccisagitta enflata, Sagitta spp., Serratosagitta serratodentata, and Pterosagitta draco) were parasitized. These species were parasitized with 33 types of flatworms and unidentified cysts (likely protozoan ciliates), having an overall mean prevalence of $6 \%$. Digenean metacercaria larvae numerically dominated the parasite assemblages. Cluster analysis defined 2 chaetognath species assemblages. One included 7 species inside Laguna Nichupté, where F. hispida was numerically dominant $(98.9 \%)$; the other contained 13 chaetognath species in the continental shelf-coral reef region, where $F$. enflata was abundant $(53 \%)$. Canonical correspondence analysis showed that Laguna Nichupté had highly variable and hostile conditions (relatively low salinity and high temperature) for chaetognath species except for $F$. hispida. The higher density of $F$. hispida promoted greater parasite diversity (23 types), dominated by Brachyphallus sp. metacercariae. F. enflata prevailed in the continental shelf-coral reef area, which had stable high salinity and relatively low temperature. Monilicaecum and unidentified digenean 'type $\mathrm{g}$ ' infected 5 chaetognath species on the continental shelf. Distinct primary hosts (mollusks and copepods) and contrasting environmental conditions (salinity, dissolved oxygen concentration, and temperature) between Laguna Nichupté and the continental shelf promoted distinct chaetognath species assemblages, resulting in distinct parasite diversity and prevalence patterns.
\end{abstract}

KEY WORDS: Endohelminths · Component community $\cdot$ Habitat partitioning - Time series · Caribbean Sea

\section{INTRODUCTION}

Chaetognaths are a major component in zooplankton assemblages worldwide and are recognized as voracious zooplanktophagous predators in the pelagic food web (Reeve 1970). They have a densitydependent influence on their prey populations, such as copepods, that dominate abundance and biomass in zooplankton assemblages (Feigenbaum \& Maris 1984, Villate 1991). Among factors that contribute to explain why chaetognaths are frequent intermediate or paratenic hosts of trophically transmitted endoparasites are that chaetognaths are rapacious and generalist carnivores (even cannibals), they can feed frequently on the first intermediate hosts, and they have relatively high population densities with broad zoo- 
geographic patterns (from epipelagic to bathypelagic habitats). Additionally, chaetognaths undertake vertical migrations, which facilitates contact with infected first intermediate mollusk hosts near the bottom in neritic areas, or with infected second intermediate hosts, such as copepods, during their daily vertical migrations (Ho \& Perkins 1985, Daponte et al. 2008). Thus, chaetognaths represent a large population biomass for parasites that facilitates parasite transmission from zooplankton to intermediate and final hosts (Ho \& Perkins 1985, Gómez del Prado-Rosas et al. 2005, Daponte et al. 2008).

Several helminth parasites affect their chaetognath hosts, causing gigantism and inducing them to swim near the surface, which results in higher vulnerability to planktophagous predators (Pearre 1976, 1979). Parasites also cause wounds in the chaetognath tegument (Nagasawa \& Nemoto 1984). Santhakumari (1992) reported that fungal infections change the color of the host, causing dark spots on the tegument of Flaccisagitta enflata and Zonosagitta bedoti, loss of transparency in the tail of F. enflata, and bumps or deformations of the body tegument (tumor-like structures). Øresland \& Bray (2005) reported several flatworm parasites infecting chaetognaths and suggested that the polychaetes Typhloscolex muelleri and Travisiopsis dubia explained headless chaetognaths observed in the samples; they also observed the copepod Microstella norwegica infecting the chaetognath head.

Chaetognaths interact with at least 13 taxonomic groups of pathogens, micropredators, and parasites using many trophic strategies; in chronological order of discovery, they are (1) Digenea, (2) Monogenea, (3) Apicomplexa, (4) Nematoda, (5) Amoebozoa, (6) Dinoflagellata, (7) Ciliata, (8) Cestoda, (9) Euglenozoa, (10) Copepoda, (11) Polychaeta, (12) Bacteria, and (13) Acanthocephala (Lozano-Cobo et al. 2017). Because most chaetognath species have broad geographic patterns, their parasites have been reported in many habitats. However, most reports were serendipitous, non-systematic, or short-term studies ( $<30 \mathrm{~d}$ ) consisting of catalogues of parasites found with a description of parasite morphology (Weinstein 1972, Jarling \& Kapp 1985). Historical research efforts complicate an emerging ecological perspective about how chaetognath species assemblages influence their parasitic species assemblages. Poulin (2007) argued that integrative parasitological studies might help to reveal consistent patterns detectable across taxa or geographical areas. Systematic zooplankton time series provide a geographically explicit and time dynamic perspective about parasite-host interactions in pelagic habitats.

To our knowledge, all monthly time series of chaetognath and parasite abundance and prevalence have been recorded in temperate coastal ecosystems (Kulachkova 1972, Weinstein 1972, Øresland 1986, Ohtsuka et al. 2004, Daponte et al. 2008) (Table 1). Kulachkova (1972) reported the prevalence of 6 parasite species of Sagitta elegans, currently valid as Parasagitta elegans, in Chupa Bay in the White Sea (19661969): Brachyphallus crenatus, Derogenes varicus, Hemiurus levinseni, Scolex pleuronectis, Pseudophyllidea sp., and Contracaecum sp. Weinstein (1972) did a comprehensive study southwest of the St. Lawrence Seaway $(1965-1966,1968)$ about the component community of parasites of the numerically dominant chaetognath $P$. elegans. The ciliate Metaphrya sagittae, the metacercariae of $H$. levinseni, and a hemiurid trematode were common parasites of $P$. elegans, while the metacercariae of the hemiurid $D$. varicus were less common and the larvae of a Contracaecum-type nematode and the cestode larvae of

Table 1. Synthesis of parasites recorded infecting chaetognaths during previous systematic zooplankton time series in the world oceans. Current valid chaetognath species names are given in parentheses

\begin{tabular}{|c|c|c|c|c|}
\hline Reference & Time series & Study area & Host species & Parasites recorded \\
\hline $\begin{array}{l}\text { Kulachkova } \\
\text { (1972) }\end{array}$ & 1966-1969 & $\begin{array}{l}\text { Chupa Bay, White } \\
\text { Sea, Russia }\end{array}$ & Sagitta elegans (Parasagitta elegans) & Digenea, Cestoda, Nematoda \\
\hline $\begin{array}{l}\text { Weinstein } \\
(1972)\end{array}$ & $\begin{array}{c}1965-1966 \\
1968\end{array}$ & $\begin{array}{l}\text { Gulf of Saint } \\
\text { Lawrence, Canada }\end{array}$ & Sagitta elegans (Parasagitta elegans) & $\begin{array}{l}\text { Ciliata, Digenea, Cestoda, } \\
\text { Nematoda }\end{array}$ \\
\hline $\begin{array}{l}\text { Øresland } \\
\text { (1986) }\end{array}$ & 1982-1983 & Plymouth, England & Sagitta setosa (Parasagitta setosa) & $\begin{array}{l}\text { Protozoa, Digenea, Cestoda, } \\
\text { Nematoda }\end{array}$ \\
\hline $\begin{array}{l}\text { Ohtsuka et al.) } \\
(2004\end{array}$ & 1999-2000 & $\begin{array}{l}\text { Seto Inland Sea, } \\
\text { Japan }\end{array}$ & $\begin{array}{l}\text { Sagitta crassa (Aidanosagitta crassa), } \\
\text { Sagitta enflata (Flaccisagitta enflata), } \\
\text { Sagitta nagae (Zonosagitta nagae) }\end{array}$ & Ciliata \\
\hline $\begin{array}{l}\text { Daponte et al. } \\
(2008)\end{array}$ & 2000-2001 & $\begin{array}{l}\text { Mar del Plata, } \\
\text { Argentina }\end{array}$ & Sagitta friderici (Parasagitta friderici) & Digenea, Cestoda, Nematoda \\
\hline
\end{tabular}


Scolex pleuronectis were quite rare. Øresland (1986) sampled 2 or 3 times per month in 1982 and 1983 off Plymouth, England, discovering 8 parasite species of Parasagitta setosa: the nematode Hysterothylacium aduncum (56\% of all parasites), 5 digeneans (the hemiurids Derogenes varicus and Lecithochirium sp., the fellodistomid Monascus filiformis, a didymozoid, and a trematode-like Adolescaria progastrica), 1 cestode, and a possible protozoan. Parasites did not affect chaetognath reproduction or cause morphological injuries. In a time series in 1999-2000 in Seto, Japan, Ohtsuka et al. (2004) investigated a histophagous parasitic ciliate of copepods, Vampyrophrya pelagica, that eats the copepod carcass after the ciliates excyst in the gut of their chaetognath predators. The most recent monthly time series of chaetognaths and their parasites was carried out in the southern hemisphere at a site on the coast of Argentina in 2000-2001, where only 1 species (Parasagitta friderici) was collected (Daponte et al. 2008). P. friderici was infected with 7 types of larval parasites (plus 1 unidentified species): Derogenes sp., Ectenurus virgulus, Lepocreadiidae, Monascus filiformis, Parahemiurus merus, and tetraphyllidean plerocercoids, as well as the copepod Corycaeus amazonicus attached to the body of chaetognaths (Daponte et al. 2008). All parasites of these 5 time series had low prevalences $(<6 \%)$, which is a common finding in the marine pelagic habitat, where the number of hosts is relatively small in relation to the water volume. The parasite diversity of temperate chaetognath species seems to be low ( $<9$ species) (Kulachkova 1972, Weinstein 1972, Øresland 1986, Ohtsuka et al. 2004, Daponte et al. 2008) (Table 1). Because previous time series studies have been monospecific, it is currently unknown how parasite species assemblages change among host chaetognath species over time, particularly in contrasting habitats where distinct chaetognath species dominate in abundance. Currently, it is unknown how parasitic species diversity interacts with chaetognaths in tropical latitudes. In this study, we analyzed tropical chaetognaths and their parasite assemblages in a shallow lagoon and adjacent continental shelf in the Caribbean Sea in 2004-2005.

Parasitism in chaetognaths in Mexico has been studied along the east coast of the state of Quintana Roo (Yucatan Peninsula), reporting digenean larvae infections (in cercaria and metacercaria stages) (Gómez del Prado-Rosas et al. 1999a,b, 2000, 2002, $2005,2007 \mathrm{~b})$. These taxonomic studies, mostly larval stage descriptions, were relevant for further ecological studies about spatial and seasonal variability of the chaetognath-parasite interaction, such as abun- dance and prevalence associated with contrasting environmental conditions. In the western Caribbean Sea, changes in chaetognath abundance are closely related to the dry and rainy seasons (Álvarez-Cadena et al. 2007, 2009). We analyzed a systematic monthly time series at 12 stations to study spatial and seasonal variability of helminth parasite and host interactions and to test the hypothesis that chaetognath species assemblages, inhabiting different habitats, may also promote distinct parasite species assemblages, especially a density-dependent association. We tested this hypothesis by comparing abundance and diversity of chaetognaths and their parasite species assemblages in a low-salinity shallow lagoon and in adjacent continental shelf-coral reef habitats. Our main goals were to (1) describe variability of chaetognath and helminth parasite habitats and seasons in terms of diversity, abundance, prevalence, and mean intensity, comparing a shallow, tropical lagoon with the adjacent continental shelf and coral reef habitats, and (2) quantitatively analyze host and parasite species assemblages (component community) as a function of temperature, salinity, $\mathrm{pH}$, concentration of dissolved oxygen, and seasonal and annual rainfall periods in 2004 and 2005. This analysis could indicate that environmental factors among different habitats and seasons enhance chaetognath host abundance and how host abundance drives diversity, prevalence, and abundance of their parasite species assemblages.

\section{MATERIALS AND METHODS}

\section{Sampling and study area}

Our study area was the northeastern coast of the Yucatan Peninsula, covering a $50 \mathrm{~km}$ shore zone from Puerto Morelos to Cancún ( $20^{\circ} 55^{\prime}$ to $21^{\circ} 05^{\prime} \mathrm{N}, 86^{\circ} 40^{\prime}$ to $86^{\circ} 50^{\prime} \mathrm{W}_{\text {; Fig. }}$ ). This area is part of the second largest coral reef system of the world. Monthly zooplankton collection was conducted in 2004 and 2005 at 12 sampling stations in 3 interconnected areas: the Laguna Nichupté (area $48 \times 10^{6} \mathrm{~m}^{2}, 2.2 \mathrm{~m}$ mean depth, 4 sites), the continental shelf, without coral reefs ( 2 sites), and coral reefs (6 sites); the latter 2 areas had a seafloor depth $<30 \mathrm{~m}$ (Fig. 1). Laguna Nichupté has a low tidal range $(3-20 \mathrm{~cm})$. The lagoon system is connected to the open sea through 2 narrow and shallow inlets (Cancún: $4 \mathrm{~m}$ deep, 30-40 m wide; Nizuc $3 \mathrm{~m}$ deep, 20-30 m wide) that promote relatively long flushing times (1.3-1.9 yr), with a characteristic east-west gradient in low salinity caused by ground- 


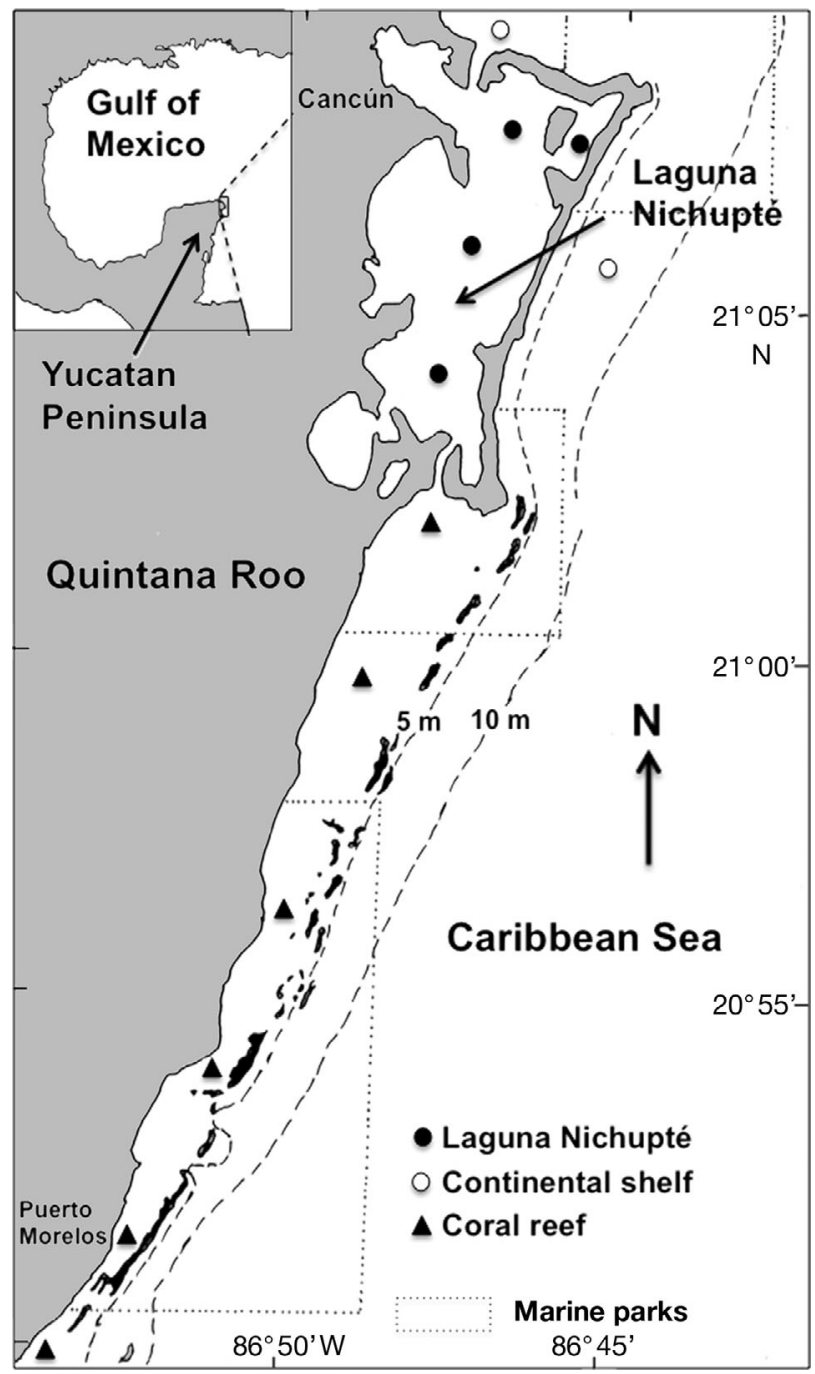

Fig. 1. Sampling stations in the Laguna Nichupté, continental shelf (without coral reefs), and coral reef areas where near-surface zooplankton were sampled every month from January 2004 through December 2005 in the State of Quintana Roo, Mexico

water discharge and rainfall, but with no significant vertical salinity gradient (Merino et al. 1990). In the Quintana Roo coastal area there is a prevailing northward current with a velocity of $>0.6 \mathrm{~m} \mathrm{~s}^{-1}$ that eventually becomes part of the Yucatan Current, which enters the Gulf of Mexico (with transient, low-intensity countercurrents) (Merino 1986, Athie et al. 2011).

Zooplankton samples were collected in a conical zooplankton net $(0.42 \mathrm{~m}$ mouth diameter, $1.2 \mathrm{~m}$ long, $330 \mu \mathrm{m}$ mesh), towed near the surface (first $5 \mathrm{~m}$ ) for $5 \mathrm{~min}$ in a circular path at a mean speed of $67 \mathrm{~m} \mathrm{~min}^{-1}$. The filtered seawater volume $\left(\mathrm{m}^{3}\right)$ was estimated following standard methods (Smith \& Richardson 1977). All samples were fixed in $4 \%$ formaldehyde solution and then neutralized with saturated sodium borate to fix the chaetognaths and their parasites. Sea surface temperature (SST), salinity, $\mathrm{pH}$, and dissolved oxygen (DO) concentration were measured with a calibrated multi-sensor. Mean and range of SST, salinity, and DO concentration were calculated per month for the entire time series to show seasonal and interannual environmental variability. Monthly mean and standard error of rainfall records from 2004 and 2005 were used to delimit the rainy season (Comisión Nacional del Agua, http://siga.cna.gob.mx/basesdeDatos.aspx).

\section{Chaetognath and parasite identification and abundance}

All chaetognaths were sorted from the entire zooplankton samples and identified to species level, using a standard taxonomic key (McLelland 1989). All chaetognaths were observed under an optical microscope to find parasites. These parasites were sorted for further taxonomic identification. Parasitized chaetognaths were dehydrated in a series of nondenatured ethanol solutions, from 30 to $100 \%$. These chaetognath specimens were stained with Gömöri Trichrome and made transparent with methyl salicylate to observe the internal organs of the parasites. Each parasitized chaetognath was mounted with synthetic resin (xylene, $60 \%$ ) for permanent slides (Salgado-Maldonado 1979) and photographed with a digital camera (Canon Power Shot A2500). Parasites were identified using taxonomic keys for each type of flatworm parasite (mostly focused on adult phases, rather than larval stages) (Yamaguti 1959, 1961, 1971, Anderson et al. 1974, Khalil et al. 1994, Gibson et al. 2002, Jones et al. 2005, Bray et al. 2008). Parasite and chaetognath total lengths were measured with a stereoscope (Carl Zeiss, SV11, 0.6-6× zoom magnification) equipped with a calibrated micrometer.

Total abundance of each chaetognath species and abundance of each parasitized chaetognath species (per type of parasite) was standardized to ind. $\mathrm{m}^{-3}$. Both were averaged per month (12 stations) and year (2004 vs. 2005) for each sampling area to show their geographical and seasonal variability. We conceptually distinguish abundance of parasitized chaetognaths from abundance of parasites because the later requires an estimate of the standardized abundance of parasitized chaetognaths, multiplied per specific parasite intensity (or alternatively, the mean intensity per parasite type). Direct parasite abundance (without inclusion of intensity) is only valid when natural parasite intensity is 1 (i.e. nematodes, acanthocephalans). 
Because several parasites have an intensity $>1$ (i.e. didymozoids and unidentified protozoan cysts), and it is not known if several parasites infect other types of hosts (beside chaetognaths), we analyzed only abundance of parasitized chaetognaths with each type of parasite. Parasite prevalence and mean intensity of infection were calculated according to Bush et al. (1997). Prevalence of all parasites of each chaetognath species was also averaged per month (12 stations) and per year to show seasonal variability in each area.

\section{Data reduction and statistical methods}

We estimated the average parasite/chaetognath size proportion (P/Csp), using the parasite mean total length $(\mathrm{TL}, \mathrm{mm})$ from specimens analyzed and the maximum chaetognath TL (mm) per host species obtained from McLelland (1989). A simple linear regression model correlated the standardized parasitized chaetognath abundance (PCA) and the standardized total chaetognath abundance (TCA) per sampling station in the 3 areas. In both equations, abundance was expressed as ind. $\mathrm{m}^{-3}$.

The association of TCA and PCA with environmental conditions was analyzed using non-parametric statistics. We prepared 2 matrices: (1) species matrix of abundance of chaetognaths parasitized with each type of parasite (123 sampling stations [rows] and 5 species of chaetognaths infected with 33 types of parasites [columns], including only sampling stations that yielded parasitized chaetognaths), (2) environmental matrix of the 123 sampling stations (rows) and 6 quantitative variables (columns): prevalence (\%), temperature $\left({ }^{\circ} \mathrm{C}\right)$, salinity, DO concentration $\left(\mathrm{mg} \mathrm{l}^{-1}\right)$, $\mathrm{pH}$, and rainfall $\left(\mathrm{mm} \mathrm{mo}^{-1}\right)$, plus 2 categorical variables: seasons (winter [Nov-Feb], dry [Mar-Jun], and rainy [Jul-Oct]) (Gasca et al. 1996, Álvarez-Cadena et al. 2007, 2008; http://siga.cna.gob.mx/basesdeDatos. aspx) and the habitat areas (Laguna Nichupté, continental shelf, and coral reef). Standardized abundance (ind. $\mathrm{m}^{-3}$ ) of each chaetognath species and parasitized chaetognath species per parasite type were $\log (x+1)$ transformed to decrease the variance of the data set (McCune et al. 2002).

We used the Sorensen distance measure and $\beta$ flexible linkage method $(\beta=0.25)$ for cluster analysis to segregate groups of chaetognath and parasite species, based on similarities of their relative abundance per sampling station (Field et al. 1982, McCune et al. 2002). A multi-response permutation procedure was applied to test for statistically significant differences between sampled groups defined with cluster analy- sis, based on abundances of parasitized chaetognaths with each type of parasite. Because this is a nonparametric statistical test, it was not necessary to assume that abundances and environmental variables were normally distributed (McCune et al. 2002).

Canonical correspondence analysis (CCA) was carried out to compare environmental variables with distribution and abundance of parasitized chaetognaths and parasites per taxonomic entity. Analysis showed season bi-plot ordination of sampling units, based on parasitized chaetognath species abundance (per parasite type), where vectors of environmental variables represent the relative contribution of total observed variance. Species and sampling stations are the dominant multidimensional patterns in the distribution of species assemblages throughout environmental gradients in time and space (Ter Braak 1986). We were particularly interested in statistically comparing differences in the abundances of chaetognaths and their parasite species between Laguna Nichupté and the continental shelf-coral reef habitats. All statistical analyses were performed using PC-ORD 6 software (McCune et al. 2002).

\section{RESULTS}

\section{Environmental conditions}

The rainy season occurred from May through October in 2004 and 2005. Anomalously high rainfall occurred from 3 'category 5 ' hurricanes that caused anomalously low salinities $(\sim 16)$ from October through December in the lagoon (Fig. 2A,C). The lagoon had lower SST (except July 2004), was considerably less saline, and had lower DO concentration than the continental shelf-coral reef area (except in April and June 2004 and February and November 2005; Fig. 2B-D). Both years had similar seasonal environmental conditions except during October to December 2005, when the lagoon had anomalously low salinity (Fig. 2C).

\section{Seasonal variability in diversity and abundance of chaetognaths and parasites}

During this study, we identified 12 chaetognath species, as well as several Sagitta spp. that could only be identified to genus level because they were mostly damaged specimens (Table 2). All species occurred in both years, except Flaccisagitta hexaptera, which was found only in 2004, and Eukrohnia hamata, which was found only in 2005. The most abundant 


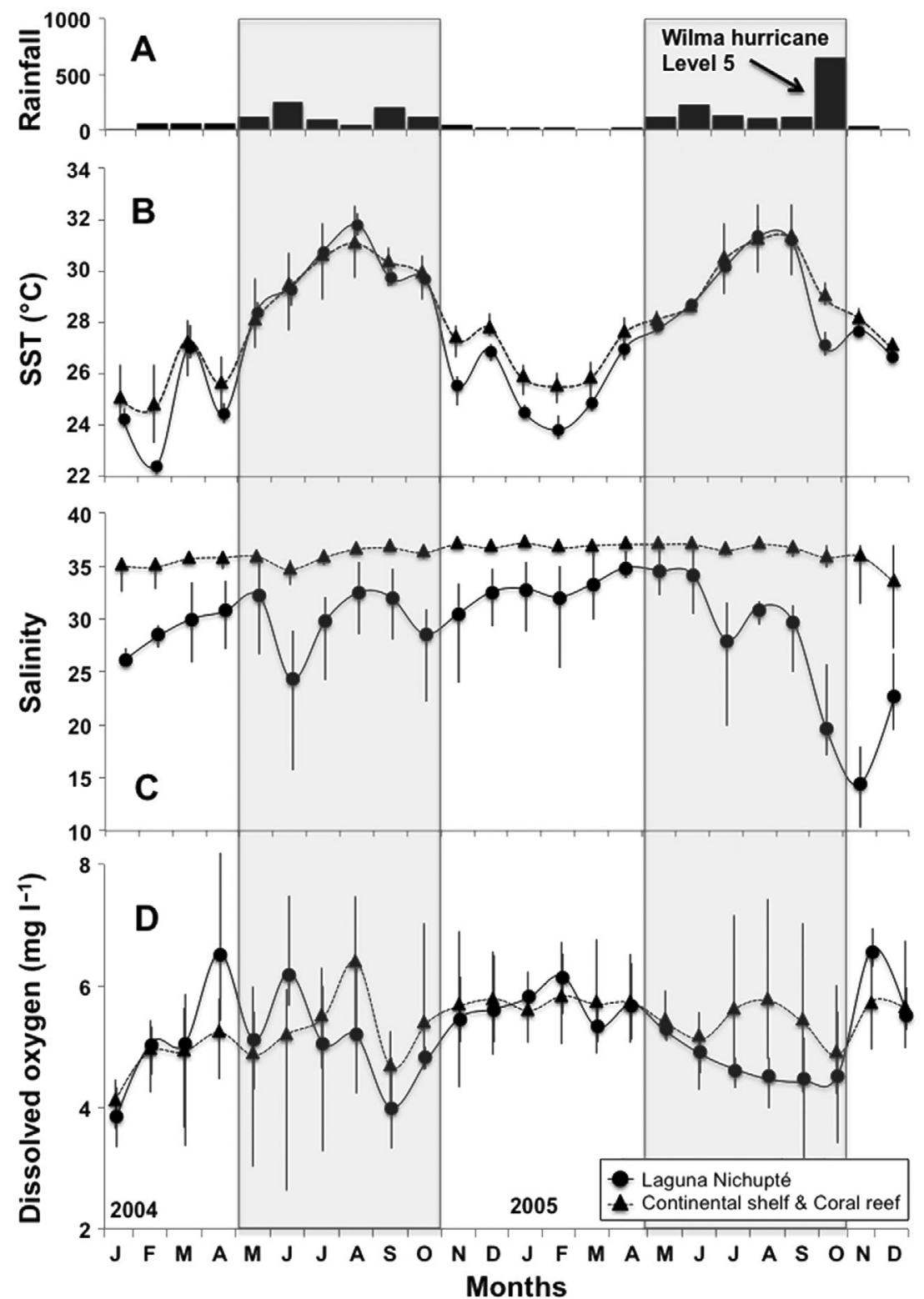

Fig. 2. Monthly time series of mean (symbols) and range (vertical bars) of environmental conditions recorded in Laguna Nichupté and the continental shelf and coral reef areas (Quintano Roo, Mexico) during 2004 and 2005. (A) Rainfall $\left(\mathrm{mm} \mathrm{mo}^{-1}\right)$. The rainy season is shown in gray. On 19 October 2005, Hurricane Wilma (category 5) reached the Yucatan Peninsula. (B) Sea surface temperature (SST, $\left.{ }^{\circ} \mathrm{C}\right)$. (C) Salinity. (D) Dissolved oxygen concentration $\left(\mathrm{mg} \mathrm{l}^{-1}\right.$ )

and in the coral reef, we found 13 chaetognath species; only 5 species were parasitized (Sagitta spp. data not shown because they were parasitized only in 2005; Fig. 3D,E).

Abundance of chaetognaths (with and without parasite infection) was generally lower during the rainy season than during the rest of the year (in both years; Fig. 3A,B,D,E). However, prevalence was typically higher during the rainy season than during the rest of the year (in both years; Fig. 3C,F). More parasitized F. hispida and $F$. enflata were recorded in 2005 than in 2004; however, overall parasite prevalence was higher in 2004 than 2005 (Fig. 3C,F). F. hispida had higher parasite prevalence $(7.75 \%)$ than the other chaetognath species (F. enflata $5.01 \%$, P. draco $4.76 \%$, and S. serratodentata $0.24 \%$ ) during 2004 . F. enflata had higher parasite prevalence $(8.99 \%)$ than the other chaetognath species (S. serratodentata $5.98 \%$, F. hispida $5.85 \%$, and Sagitta spp. $1.32 \%$ ) during 2005.

We found highly diverse parasite assemblages (component community), composed of monogeneans, digeneans, cestodes, nematodes, and multiple unidentified protozoan cysts, including 33 distinct types of parasites identified to several taxonomic levels (Tables 3 \& 4, Fig. 4). Most flatworm parasites were identified to genus level because helminth larvae have few structures of taxonomic value and there are few taxonomic keys for this life phase. Protozoan cysts and digenean trematodes were the most abundant and prevalent parasites infecting chaetognaths during both years, whereas the prevalence and abundance of cestodes, nematodes,

species, Ferosagitta hispida (87.6\%), Flaccisagitta enflata (6.6\%), and Sagitta spp. (2.4\%), as well as the fifth (Serratosagitta serratodentata, 0.9\%) and the seventh (Pterosagitta draco, 0.3\%) most abundant species were the only species infected with parasites (Table 2, Fig. 3). Of 7 chaetognath species found in Laguna Nichupté, 5 were parasitized. F. hispida accounted for $98.9 \%$ of the chaetognath population in the lagoon (Fig. 3A,B). On the continental shelf and monogeneans were lower. One monogenean larva was found at a station in 2004 on the continental shelf; it was an ectoparasite attached by 2 posterior hooks to the tegument of the middle part of the body of an F. enflata (Tables 3 \& 4). Monogeneans and nematodes had an average intensity of 1 parasite host ${ }^{-1}$, cestodes and digeneans had a mean intensity ranging between 1.0 and 1.9, and unidentified protozoan cysts had a mean intensity from 1.84 to 3.04 (Table 3). 
Table 2. Total number and relative abundance (\%) of specimens of each chaetognath species collected and evaluated for the presence of parasites in the northern region of Quintana Roo (Caribbean Sea, Mexico) in 2004 and 2005. Chaetognath species highlighted in bold were infected with at least 1 type of parasite

\begin{tabular}{|c|c|c|c|c|c|}
\hline $\begin{array}{l}\text { Chaetognath family } \\
\text { and authority }\end{array}$ & Species and authority & 2004 & 2005 & Total & $\begin{array}{c}\text { Relative } \\
\text { abundance (\%) }\end{array}$ \\
\hline Eukrohniidae Tokioka, 1965 & Eukrohnia hamata (Mobius, 1875) & 0 & 3 & 3 & 0.0 \\
\hline Krohnittidae Tokioka, 1965 & Krohnitta pacifica (Aida, 1897) & 505 & 497 & 1002 & 1.5 \\
\hline Pterosagittidae Tokioka, 1965 & Pterosagitta draco (Krohn, 1853) & 126 & 44 & 170 & 0.3 \\
\hline Sagittidae Claus and & Ferosagitta hispida (Conant, 1895) & 13189 & 45697 & 58886 & 87.6 \\
\hline \multirow[t]{9}{*}{ Grobben, 1905} & Flaccisagitta enflata (Grassi, 1881) & 2477 & 1935 & 4412 & 6.6 \\
\hline & Flaccisagitta hexaptera (d'Orbigny, 1843) & 44 & 0 & 44 & 0.1 \\
\hline & Mesosagitta minima (Grassi, 1881) & 2 & 86 & 88 & 0.1 \\
\hline & Parasagitta helenae Ritter-Zahony, 1910 & 7 & 28 & 35 & 0.1 \\
\hline & Parasagitta friderici Ritter-Zahony, 1911 & 7 & 16 & 23 & 0.0 \\
\hline & Parasagitta tenuis Conant, 1896 & 189 & 54 & 243 & 0.4 \\
\hline & Sagitta bipunctata Quoy \& Gaimard, 1827 & 1 & 75 & 76 & 0.1 \\
\hline & Sagitta spp. & 859 & 756 & 1615 & 2.4 \\
\hline & Serratosagitta serratodentata (Krohn, 1853) & 419 & 184 & 603 & 0.9 \\
\hline \multicolumn{2}{|c|}{ Total chaetognath specimens analyzed (N) } & 17825 & 49375 & 67200 & \\
\hline \multicolumn{2}{|c|}{ Total parasitized chaetognath specimens analyzed (np) } & 1153 & 2867 & 4020 & \\
\hline \multicolumn{2}{|l|}{ Prevalence $\%[(\mathrm{np} / \mathrm{N}) \times 100]$} & 6.47 & 5.81 & 5.98 & \\
\hline
\end{tabular}

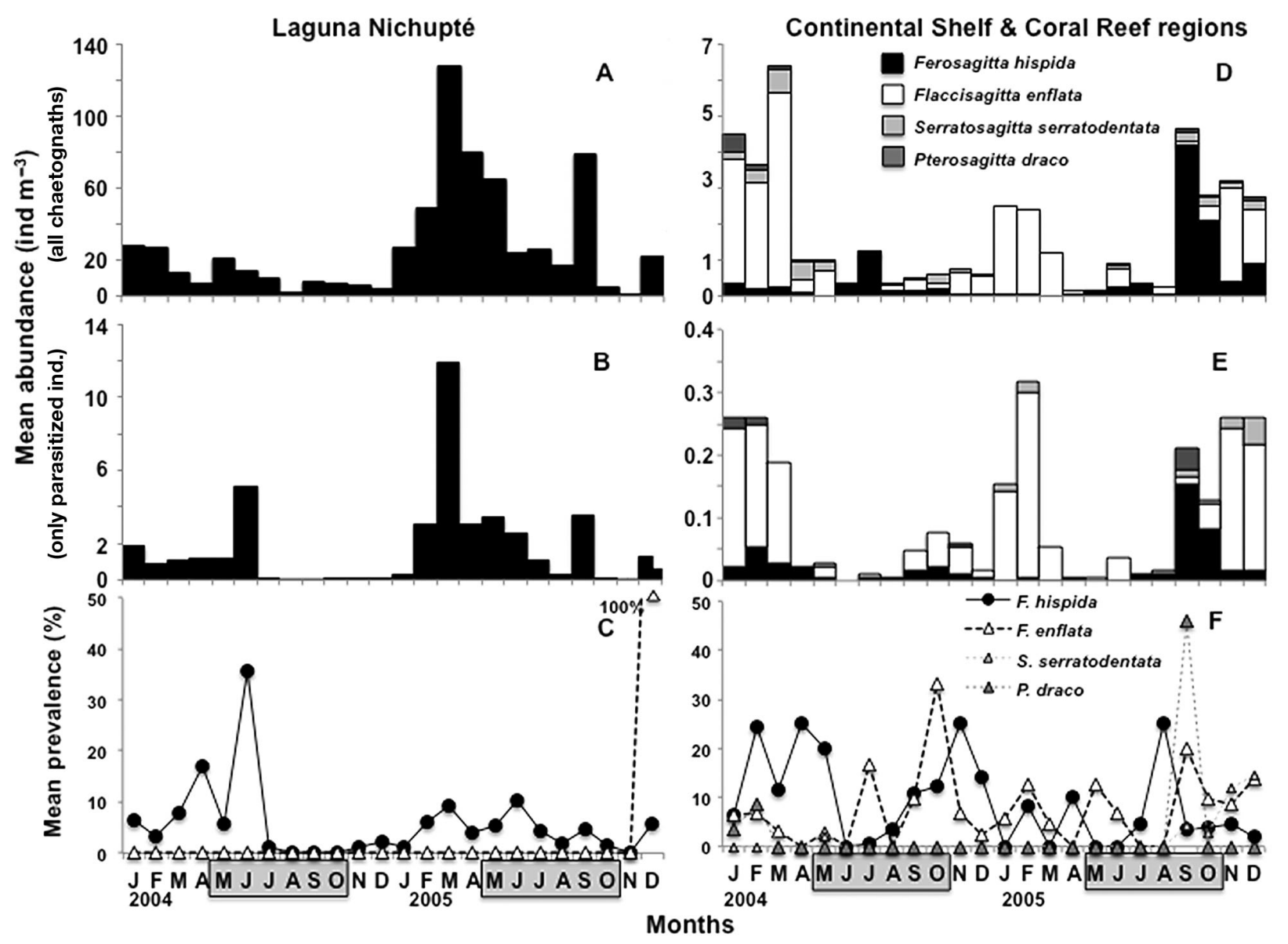

Fig. 3. Monthly mean abundance (ind. $\mathrm{m}^{-3}$ ) of 4 of 5 chaetognath species that were parasitized (Sagitta spp. infection is not shown) for $(A, D)$ all individuals and $(B, E)$ only parasitized individuals. $(C, F)$ Prevalence rates per species recorded at Laguna Nichupté and continental shelf-coral reef regions during the 2004-2005 time series. Grey shading indicates rainy season 
Table 3. Number of parasitized chaetognath hosts per type of parasite, prevalence $(\%)$, number of parasites observed, and mean intensity of each type of parasite that was found to infect chaetognaths in the Caribbean Sea, northern region of Quintana Roo, Mexico (17 825 chaetognaths analyzed in 2004; 49375 chaetognaths analyzed in 2005). Values shown are results for 2004 / 2005

\begin{tabular}{|lcccc|}
\hline $\begin{array}{l}\text { Parasite } \\
\text { type }\end{array}$ & $\begin{array}{c}\text { Total number of } \\
\text { parasitized hosts }\end{array}$ & $\begin{array}{c}\text { Prevalence } \\
(\%)\end{array}$ & $\begin{array}{c}\text { Total number } \\
\text { of parasites }\end{array}$ & $\begin{array}{c}\text { Mean } \\
\text { intensity }\end{array}$ \\
\hline Monogenea & $1 / 0$ & $0.01 / 0$ & $1 / 0$ & $1 / 0$ \\
Digenea & $343 / 438$ & $1.92 / 0.89$ & $648 / 491$ & $1.89 / 1.12$ \\
Cestoda & $4 / 7$ & $0.02 / 0.01$ & $6 / 7$ & $1.5 / 1$ \\
Nematoda & $2 / 1$ & $0.01 / 0$ & $2 / 1$ & $1 / 1$ \\
Protozoan cysts & $1146 / 2789$ & $6.43 / 5.65$ & $3480 / 5133$ & $3.04 / 1.84$ \\
\hline
\end{tabular}

Monthly records showed that abundance of parasitized chaetognaths and richness of parasite species was considerably higher during the dry season than during the May to October rainy season (except in June 2004 when parasitized chaetognaths were also abundant), higher in 2004 than in 2005, and considerably higher in the lagoon than on the continental shelf and coral reef (Fig. 5). Unidentified protozoan cysts and Hemiuridae found favorable conditions to parasitize $F$. hispida and dominated the lagoon parasite assemblage (Fig. 5A,C). Monilicaecum (a digenean) and unidentified protozoan cysts were the dominant parasites infecting 5 chaetognath species on the continental shelf and coral reef (Fig. 5B,D). Thus, considerably different parasite assemblages were observed inside and outside the lagoon. Parasitized chaetognath abundance (PCA) had a significant negative density-dependent relationship with total chaetognath abundance (TCA) in the lagoon $\left[\mathrm{PCA}=0.00071(\mathrm{TCA})-0.2325\left(\mathrm{r}^{2}=0.71\right)\right]$ and on the coastal shelf and coral reef $[\mathrm{PCA}=0.079 \mathrm{Ln}(\mathrm{TCA})-$ $\left.0.0275\left(\mathrm{r}^{2}=0.65\right)\right]$. This means that higher prevalence rates were mostly observed at sampling stations where chaetognaths had low abundance.

\section{Parasite/host size proportion}

The mean parasite-chaetognath host size proportion (P/Csp) of the 5 parasitized chaetognaths was small (0.052) (Table 5). F. hispida, with a maximum TL of $12 \mathrm{~mm}$, had the highest mean P/Csp (0.243), while the larger $S$. serratodentata had a mean P/Csp of 0.008 , based on the relatively small size of parasites. Although $F$. enflata had the largest maximum TL $(25 \mathrm{~mm})$, the mean P/Csp was 0.23 because $F$. enflata was infected with several relatively large parasites, i.e. nematodes and Procamallanus species (Table 5). The smallest P/Csp occurred among un- identified protozoan cysts that were present in all parasitized chaetognath species (Table 5).

\section{Abundance of chaetognaths and parasites associated with environmental conditions}

Cluster analysis provided 2 groups of sampling stations at a cutoff at $12 \%$ of similarity, based on location and abundance of chaetognaths, parasitized chaetognaths, and composition of parasite species. Species in the first group were numerically dominated by $F$. hispida, which mostly inhabited the lagoon (Group 1: F. hispida). Species in the second group, numerically dominated by $F$. enflata, were mostly found on the continental shelf and coral reef (Group 2: F. enflata) (Fig. 6).

Group 1 was divided into 2 subgroups, of which one included only sampling stations from the lagoon (both years), where F. hispida was present in high abundance and $F$. enflata in low abundance (Subgroup 1A). Subgroup 1A included 45 sampling stations in the lagoon $(40 \%$ of the samples were collected in 2004 [January-July] and 60\% in 2005 [JanuarySeptember, December]; Table 4). In this subgroup, $F$. hispida and $F$. enflata were infected with 24 types of parasites. F. hispida was numerically dominant, with a mean abundance of 0.54 ind. $\mathrm{m}^{-3}$ and present at all sampling stations. Unidentified protozoan cysts were the most prevalent parasites, with a mean abundance of 1.86 ind. $\mathrm{m}^{-3}$ and present at all sampling stations. The mean parasite prevalence inside Laguna Nichupté was particularly high $(10.3 \%$, range: $0.74-85.6 \%)$, and parasitized hosts were living in a habitat with the lowest mean salinity recorded, with relatively low mean temperature, rainfall, oxygen concentration, and high $\mathrm{pH}$ (Table 4).

The second subgroup, 1B, included 18 sampling stations at which most samples were collected during $2005(72 \%$, vs. $28 \%$ in 2004) from the 3 areas (mostly outside the inlets of the lagoon), where $F$. hispida had low abundance. Subgroup 1B included mostly samples collected from the stations inside the lagoon $(55 \%)$, followed by the coral reef $(39 \%)$ and continental shelf $(1 \%)$ and included 5 parasitized chaetognath species. F. hispida was the dominant species, with a low mean abundance of 0.12 ind. $\mathrm{m}^{-3}$ and present at all continental shelf-coral reef sampling stations. There were 11 distinct types of parasites. Unidentified protozoan cysts $\left(0.03\right.$ ind. $\left.\mathrm{m}^{-3}\right)$ and the 
Table 4. (A) Mean abundance (ind. $\mathrm{m}^{-3}$ ) and relative frequency (\%) of the 5 parasitized chaetognath species and their parasites, and (B) mean environmental conditions per sampling group, resulting in 2 cluster analysis groups of stations with distinct chaetognath species assemblages: one group was numerically dominated by Ferosagitta hispida in Laguna Nichupté (LN) and the other was dominated by Flaccisagitta enflata on the continental shelf (CS). Each group was subdivided in 2 subgroups. The total number of zooplankton samples collected at the 12 sampling stations during 2004-2005 is shown in parentheses for each subgroup

\begin{tabular}{|c|c|c|c|c|c|c|c|c|c|}
\hline \multirow{3}{*}{$\begin{array}{l}\text { (A) } \\
\text { Abundance }\end{array}$} & \multirow{3}{*}{$\begin{array}{l}\text { Species } \\
\text { abbrev. }\end{array}$} & \multicolumn{4}{|c|}{ Group 1: Ferosagitta hispida -} & \multicolumn{4}{|c|}{ Group 2: Flaccisagitta enflata } \\
\hline & & \multicolumn{2}{|c|}{$\begin{array}{l}\text { Subgroup 1A } \\
\text { LN }(\mathrm{n}=45)\end{array}$} & \multicolumn{2}{|c|}{$\begin{array}{l}\text { Subgroup 1B } \\
\text { LN-CS }(\mathrm{n}=18)\end{array}$} & \multicolumn{2}{|c|}{$\begin{array}{c}\text { Subgroup 2A } \\
\text { CS } 2004(\mathrm{n}=19)\end{array}$} & \multicolumn{2}{|c|}{$\begin{array}{c}\text { Subgroup 2B } \\
\text { CS } 2005 \text { (n = 41) }\end{array}$} \\
\hline & & $\begin{array}{l}\text { Mean } \\
\text { abund. }\end{array}$ & $\begin{array}{l}\text { Relative } \\
\text { frequency }\end{array}$ & $\begin{array}{l}\text { Mean } \\
\text { abund. }\end{array}$ & $\begin{array}{l}\text { Relative } \\
\text { frequency }\end{array}$ & $\begin{array}{l}\text { Mean } \\
\text { abund. }\end{array}$ & $\begin{array}{c}\text { Relative } \\
\text { frequency }\end{array}$ & $\begin{array}{l}\text { Mean } \\
\text { abund. }\end{array}$ & $\begin{array}{l}\text { Relative } \\
\text { frequency }\end{array}$ \\
\hline \multicolumn{10}{|l|}{ Chaetognath hosts } \\
\hline Ferosagitta hispida & $F h$ & 54.07 & 100.0 & 10.69 & 100.0 & 0.15 & 84.2 & 0.49 & 85.4 \\
\hline Flaccisagitta enflata & $\mathrm{Fe}$ & 0.01 & 8.9 & 0.07 & 44.4 & 0.80 & 68.4 & 4.27 & 100.0 \\
\hline Sagitta spp. & Sspp. & & & 0.17 & 38.9 & 0.34 & 57.9 & 0.33 & 58.5 \\
\hline Serratosagitta serratodentata & Ss & & & 0.17 & 38.9 & 0.34 & 57.9 & 0.33 & 58.5 \\
\hline Pterosagitta draco & $P d$ & & & 0.03 & 16.7 & 0.03 & 31.6 & 0.16 & 41.5 \\
\hline \multicolumn{10}{|l|}{ Parasites } \\
\hline Gyrodactylidae larva & $\mathrm{Gl}$ & & & & & & & 0.02 & 2.4 \\
\hline Cercaria owreae & $\mathrm{Co}$ & & & & & 0.11 & 10.5 & 0.10 & 4.9 \\
\hline Monilicaecum type & Mo & 0.13 & 6.7 & 0.28 & 22.2 & 0.11 & 10.5 & 5.61 & 100.0 \\
\hline Hemiuridae & $\mathrm{He}$ & 3.62 & 44.4 & 0.89 & 44.4 & & & 0.12 & 9.8 \\
\hline Hemiurus sp. & Hsp & 0.31 & 15.6 & 0.11 & 5.6 & & & & \\
\hline Parahemiurus sp. & Phsp & 0.29 & 24.4 & & & & & & \\
\hline Lecithochirium sp. & $L s p$ & 0.27 & 15.6 & 0.56 & 16.7 & & & & \\
\hline Brachyaphallus sp. & $B$ sp & 0.67 & 24.4 & 1.44 & 33.3 & & & 0.02 & 2.4 \\
\hline Paralecithochirium sp. & Plsp & & & & & & & 0.02 & 2.4 \\
\hline Opisthadena sp. & Osp & 0.02 & 2.2 & & & 0.05 & 5.3 & & \\
\hline Dinosoma sp. & $D$ sp & 0.20 & 11.1 & 0.44 & 22.2 & & & 0.05 & 4.9 \\
\hline Opechona pyriforme & $O p$ & 0.02 & 2.2 & & & & & 0.27 & 17.1 \\
\hline Tergestia sp. & $T \mathrm{sp}$ & 0.02 & 2.2 & 0.44 & 11.1 & & & 0.07 & 2.4 \\
\hline Digenea a & da & & & & & & & 0.02 & 2.4 \\
\hline Digenea b & $\mathrm{db}$ & & & & & & & 0.02 & 2.4 \\
\hline Digenea c & dc & 0.02 & 2.2 & & & & & & \\
\hline Digenea d & $\mathrm{dd}$ & 0.02 & 2.2 & & & & & & \\
\hline Digenea e & de & 0.02 & 2.2 & & & & & & \\
\hline Digenea f & $\mathrm{df}$ & 0.02 & 2.2 & & & & & 0.02 & 2.4 \\
\hline Digenea $g$ & $\mathrm{dg}$ & 10.47 & 33.3 & 0.39 & 16.7 & 0.42 & 21.1 & 1.27 & 31.7 \\
\hline Sporocyst & Spor & 0.13 & 4.4 & & & & & & \\
\hline Plerocercoid a & pa & 0.02 & 2.2 & & & & & & \\
\hline Plerocercoid b & $\mathrm{pb}$ & 0.16 & 8.9 & & & & & & \\
\hline Plerocercoid c & pc & & & & & & & 0.02 & 2.4 \\
\hline Plerocercoid d & $\mathrm{pd}$ & & & & & 0.05 & 5.3 & & \\
\hline Plerocercoid e & pe & & & & & & & 0.02 & 2.4 \\
\hline Plerocercoid f & pf & & & & & & & 0.05 & 2.4 \\
\hline Nematode larva & $\mathrm{Nl}$ & 0.02 & 2.2 & & & & & 0.02 & 2.4 \\
\hline $\begin{array}{l}\text { Procamallanus } \\
\text { (Spirocamallanus) sp. }\end{array}$ & $P_{S} \mathrm{sp}$ & & & & & & & 0.02 & 2.4 \\
\hline Platyhelminth a & plaa & 0.02 & 2.2 & & & & & & \\
\hline Platyhelminth b & plab & 0.22 & 15.6 & 0.06 & 5.6 & & & & \\
\hline Platyhelminth c & plac & 0.02 & 2.2 & & & & & & \\
\hline Unidentified protozoan cysts & $\mathrm{uPC}$ & 186.16 & 100.0 & 3.00 & 55.6 & 1.42 & 79.0 & 4.02 & 61.0 \\
\hline \multicolumn{10}{|l|}{ (B) } \\
\hline Environmental conditions & Abbrev. & Mean & Range & Mean & Range & Mean & Range & Mean & Range \\
\hline Prevalence (\%) & $\mathrm{P}$ & 10.3 & $0.74-85.6$ & 2.5 & $0.32-8.0$ & 8.5 & $0.00001-33$ & 10.9 & $1.61-33.3$ \\
\hline Temperature $\left({ }^{\circ} \mathrm{C}\right)$ & $\mathrm{T}$ & 27.5 & $22.1-32.6$ & 28.7 & $24.7-32.6$ & 27.9 & 23.9-32.2 & 26.8 & $24.2-29.4$ \\
\hline Salinity & $\mathrm{S}$ & 31.11 & $20.8-36.75$ & 33.05 & $19.4-37.3$ & 35.16 & $27.2-37.4$ & 36.08 & $27.3-37.65$ \\
\hline Dissolved oxygen $\left(\mathrm{mg} \mathrm{l}^{-1}\right)$ & DO & 5.02 & $3.25-7.0$ & 5.45 & $3.98-7.04$ & 5.34 & $3.03-7.49$ & 5.19 & $3.64-6.74$ \\
\hline $\mathrm{pH}$ & $\mathrm{pH}$ & 8.12 & $7.58-8.51$ & 7.90 & $7.21-8.28$ & 8.01 & $7.27-8.37$ & 8.11 & $7.39-8.32$ \\
\hline Rainfall (mm yr ${ }^{-1}$ ) & $\mathrm{R}$ & 79.8 & $8.6-249.9$ & 217.6 & $16-649.2$ & 75.3 & $8.6-208.2$ & 81.4 & $8.6-649.2$ \\
\hline
\end{tabular}




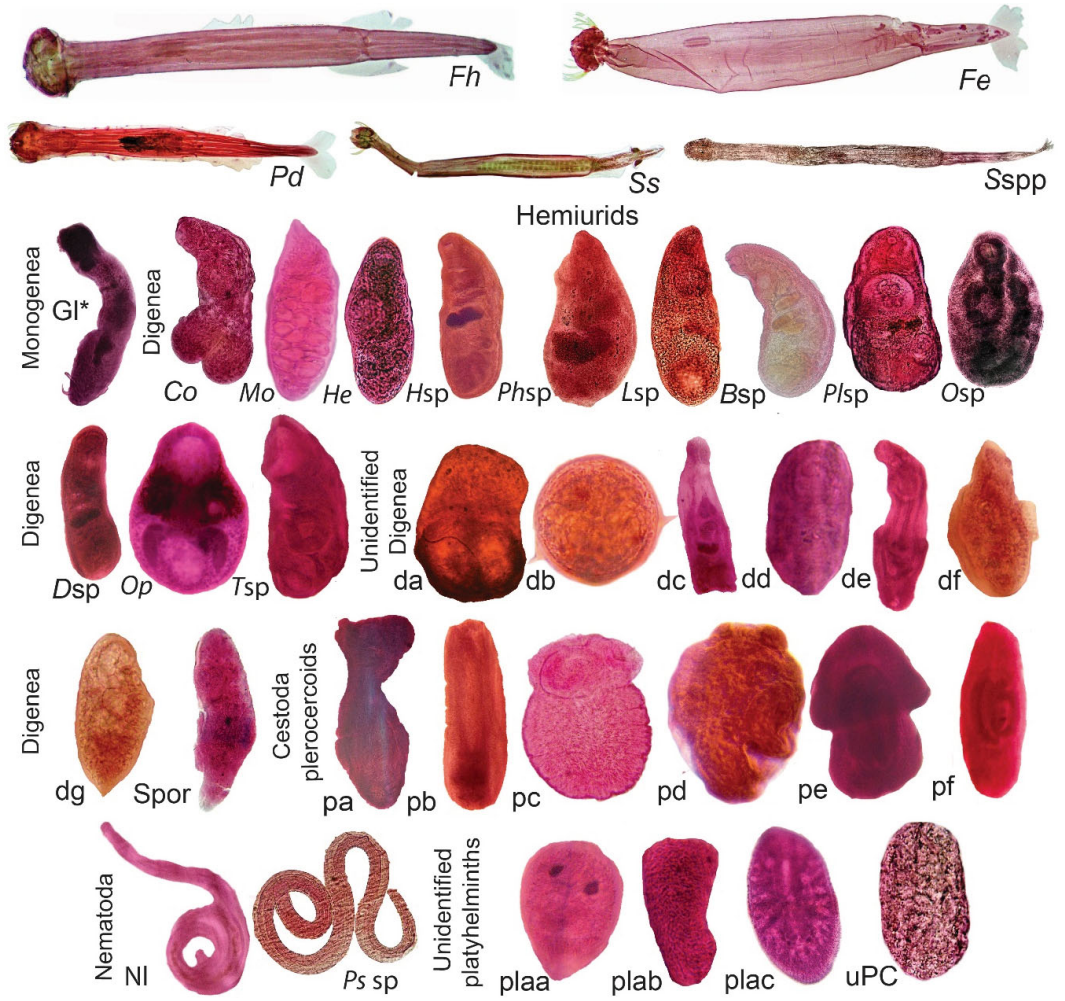

Fig. 4. Diversity of parasites that were found to infect chaetognaths in Quintana Roo, Mexico (2004-2005). Hosts are shown in the top 2 rows. All abbreviations are defined in Table 4

hemiurid Brachyphallus sp. (0.01 ind. $\mathrm{m}^{-3}$ ) were the most abundant parasites. The mean prevalence was the lowest in the study area $(2.5 \%$, range: $0.3-8.0 \%)$. This mixed area had the highest mean temperature $\left(28.7^{\circ} \mathrm{C}\right.$; range: $\left.24.7-32.6^{\circ} \mathrm{C}\right)$ and annual rainfall (217.6 $\mathrm{mm} \mathrm{yr}^{-1}$; range: $16-649.2 \mathrm{~mm} \mathrm{yr}^{-1}$ ) of the coastal area and relatively low salinity caused by the mix of lagoon and the continental shelf waters (Table 4).

Group 2 had 2 subgroups of sampling stations from the continental shelf and coral reef. Subgroup 2A was dominated by $F$. enflata and included a larger number of zooplankton samples collected in 2004 (68\%). Subgroup 2B included more zooplankton collected during 2005 (61\%). The shift in composition between 2004 and 2005 suggests a considerable interannual change in species and abundance of chaetognath parasites.

In Subgroup 2A, most of the sampling stations were in the coral reef $(47 \%)$. Although $F$. enflata had relatively low abundance $\left(0.008\right.$ ind. $\left.\mathrm{m}^{-3}\right)$ and a moderate frequency of appearance $(68 \%)$, this was the species with the highest abundance of 5 parasitized chaetognath species in the subgroup. F. hispida was frequently sampled in this region $(84 \%)$, but had very low abundance (0.002 ind. $\mathrm{m}^{-3}$ ). Unidentified protozoan cyst parasites were most abundant $\left(0.014\right.$ ind. $\left.\mathrm{m}^{-3}\right)$ and frequent $(79 \%)$, followed by the unidentified digenean type $\mathrm{g}$ (0.004 ind. $\mathrm{m}^{-3}$ and $21 \%$ ). The mean parasite prevalence of this subgroup was moderate $(8.51 \%$; range: $0.00001-$ $33 \%)$. SST at stations in this subgroup was high (mean $27.9^{\circ} \mathrm{C}$; range: $23.9-32.2^{\circ} \mathrm{C}$ ). This area received the lowest annual rainfall, resulting in a highly saline habitat with high DO content (Table 4).

In Subgroup 2B, F. enflata was the most abundant (0.042 ind. $\mathrm{m}^{-3}$ ) and frequent $(100 \%)$ chaetognath species (Table 4). There were 5 parasitized chaetognath species, with a diverse assemblage of 20 distinct types of parasites (Table 4). The Monilicaecum larval type $\left(0.056\right.$ ind. $\left.\mathrm{m}^{-3}\right)$, unidentified protozoan cysts $\left(0.040\right.$ ind. $\left.\mathrm{m}^{-3}\right)$, and digenean type $\mathrm{g}\left(0.013\right.$ ind. $\left.\mathrm{m}^{-3}\right)$ were the most abundant parasites in this subgroup of sampling stations. Mean prevalence of chaetognath parasites was the highest recorded in the study area (mean $11 \%$; range: $1.61-$ $33.3 \%)$. Stations had the lowest mean surface temperature $\left(26.8^{\circ} \mathrm{C}\right)$ and the highest mean surface salinity (36.08) in the study area (Table 4$)$. The multiresponse permutation procedure analysis showed significant differences among the 4 subgroups ( $t$-statistic: $-48.9098, A=0.5061, \mathrm{p}=0.0001$ ).

\section{CCA}

Three environmental ordination axes explained $10.1 \%$ of the variation among chaetognaths and abundance of parasitized chaetognaths in terms of habitat and seasons. The first axis showed a low gradient in salinity in the lagoon, with $F$. hispida being numerically dominant (upper part of the ordination) to a relatively high salinity across the continental shelf and coral reef and high diversity of chaetognaths and parasites (lower part of the ordination). Along axis 1, F. hispida was positively correlated with temperature, concentration of DO, and rainfall and negatively correlated with salinity and $\mathrm{pH}$ (Fig. 7; Table 5). Along axis 2, the gradient of diversity of parasites showed a high correlation with prevalence in the left part of the ordination 


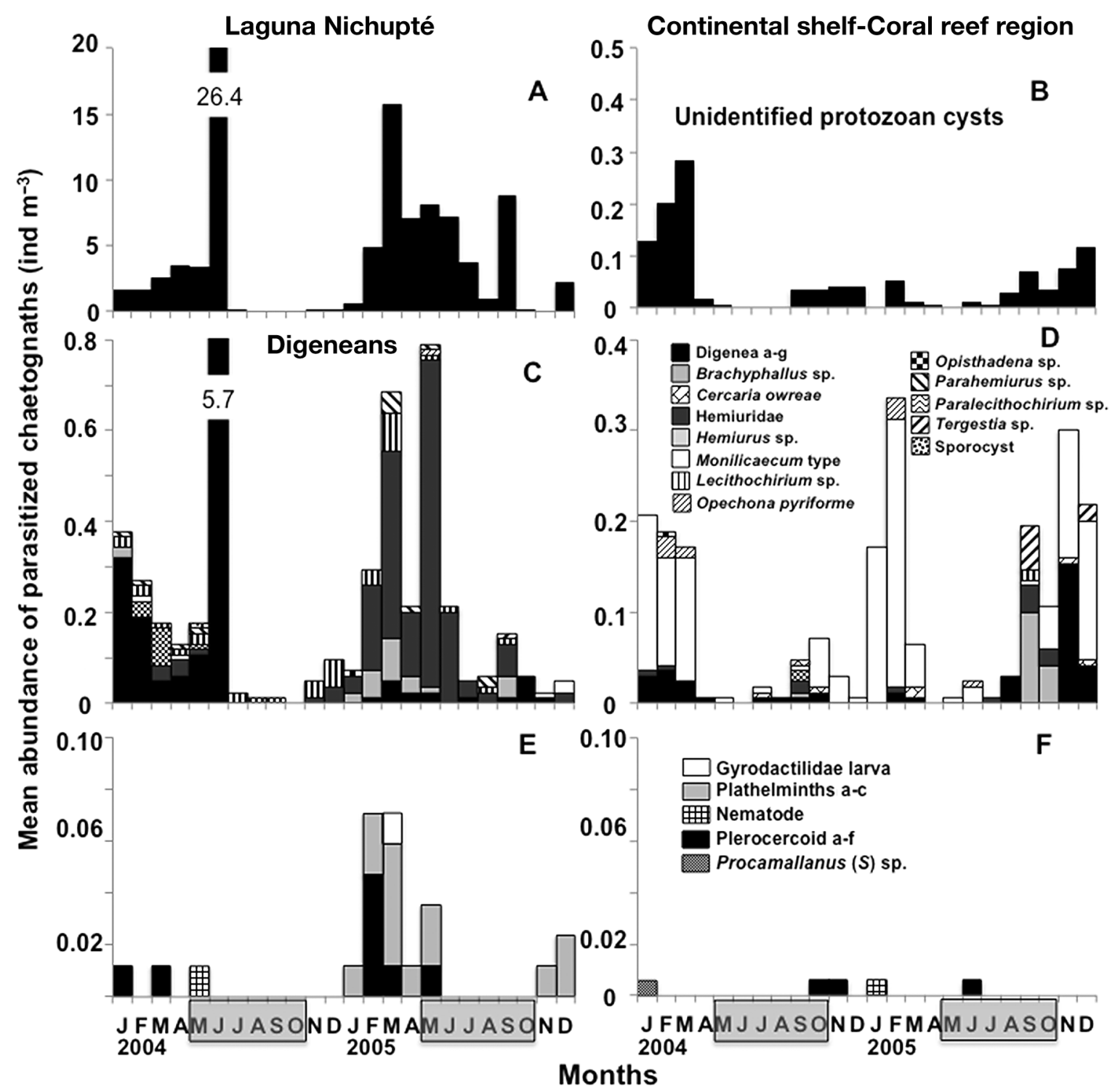

Fig. 5. Comparison of monthly mean abundance (ind. $\mathrm{m}^{-3}$ ) of parasitized chaetognaths (per type of parasite) recorded at Laguna Nichupté and continental shelf-coral reef regions during the 2004-2005 time series: (A, B) unidentified protozoan cysts, $(\mathrm{C}, \mathrm{D})$ several digenean parasites, and (E, F) monogenean, platyhelminth, and nematode parasites obtained from each region

and $\mathrm{pH}$ and the less prevalent parasites in the right part of the ordination graph. Subgroups $1 \mathrm{~A}$ and $1 \mathrm{~B}$ were correlated with high temperatures and low salinity, environmental conditions typical of the lagoon. Sampling stations in Subgroups 2A and 2B had positive correlations with high salinities and relatively low temperatures. Group 2 and Subgroup 1A were correlated with the highest levels of parasite prevalence (Fig. 7). This analysis indicates that the distinct conditions in the lagoon and its composition of chaetognath and parasite species are more related than across the continental shelf and coral reef (Fig. 7).

\section{DISCUSSION}

\section{Seasonal variability in chaetognath and parasite diversity and abundance}

This is the first systematic time series to estimate monthly changes in abundance and prevalence of multiple chaetognath and parasite species associated with environmental variability in a neritic tropical coastal ecosystem. Previous time series investigated single chaetognath host species over time in coastal temperate ecosystems, viz. the St. Lawrence Seaway (Weinstein 1972), White Sea (Kulachkova 
Table 5. Parasite/chaetognath size proportion (P/Csp) estimated using mean parasite total length (TL, mm) recorded in the northern region of Quintana Roo (Caribbean Sea, Mexico) in 2004 and 2005 and maximum TL (mm) (as reported by McLelland 1989) for 5 chaetognath hosts. -: Parasite not present in a chaetognath species; nm: parasite present, but TL was not measured

\begin{tabular}{|c|c|c|c|c|c|c|}
\hline \multirow{2}{*}{ Parasite } & \multirow{2}{*}{$\begin{array}{c}\text { Parasite } \\
\text { mean } \\
\text { TL }\end{array}$} & \multicolumn{5}{|c|}{ - P/Csp } \\
\hline & & $\begin{array}{l}\text { Ferosagitta hispida } \\
\qquad(\mathrm{TL}=12)\end{array}$ & $\begin{array}{c}\text { Flaccisagitta } \\
\text { enflata }(\mathrm{TL}=25)\end{array}$ & $\begin{array}{c}\text { Serratosagitta serra- } \\
\text { todentata }(\mathrm{TL}=13)\end{array}$ & $\begin{array}{c}\text { Pterosagitta } \\
\text { draco }(\mathrm{TL}=13)\end{array}$ & $\begin{array}{l}\text { Sagitta spp. } \\
(\mathrm{TL}=19)\end{array}$ \\
\hline Gyrodactylidae larva & 0.220 & _- & 0.009 & _- & _- & _- \\
\hline Cercaria owreae & 0.031 & - & 0.001 & - & - & - \\
\hline Monilicaecum type & 0.148 & 0.012 & 0.006 & 0.011 & 0.011 & 0.008 \\
\hline Hemiuridae & 0.201 & 0.017 & 0.008 & 0.015 & - & 0.011 \\
\hline Parahemiurus sp. & 0.358 & 0.030 & - & - & - & - \\
\hline Lecithochirium sp. & 0.195 & 0.016 & - & - & - & - \\
\hline Brachyaphallus sp. & 0.373 & 0.031 & 0.015 & 0.029 & - & 0.020 \\
\hline Paralecithochirium sp. & 0.269 & 0.022 & - & - & - & - \\
\hline Opisthadena sp. & 0.450 & 0.038 & 0.018 & - & - & - \\
\hline Dinosoma sp. & 0.239 & 0.020 & 0.010 & - & - & 0.013 \\
\hline Opechona pyriforme & 0.166 & 0.014 & 0.007 & - & - & - \\
\hline Tergestia sp. & 0.143 & 0.012 & 0.006 & - & - & 0.008 \\
\hline Digenea a & 0.093 & - & 0.004 & - & - & - \\
\hline Digenea b & 0.064 & - & 0.003 & - & - & - \\
\hline Digenea c & 0.623 & 0.052 & - & - & - & - \\
\hline Digenea d & 0.092 & 0.008 & - & - & - & - \\
\hline Digenea e & 0.365 & 0.030 & - & - & - & - \\
\hline Digenea f & 0.112 & 0.009 & - & - & - & - \\
\hline Digenea $g$ & 0.160 & 0.013 & 0.006 & - & 0.012 & - \\
\hline Sporocyst & 0.210 & 0.018 & - & - & - & - \\
\hline Plerocercoid a & 0.282 & 0.024 & - & - & - & - \\
\hline Plerocercoid b & 0.056 & 0.005 & - & 0.004 & - & - \\
\hline Plerocercoid c & 0.150 & - & 0.006 & - & - & - \\
\hline Plerocercoid d & 0.256 & - & 0.010 & - & - & - \\
\hline Plerocercoid e & 0.369 & 0.031 & - & 0.028 & - & - \\
\hline Plerocercoid f & 0.435 & - & 0.017 & - & - & - \\
\hline Nematode larva & 0.310 & 0.026 & 0.012 & - & - & - \\
\hline $\begin{array}{l}\text { Procamallanus (Spiro- } \\
\text { camallanus) sp. }\end{array}$ & 0.960 & 0.080 & - & - & - & - \\
\hline Platyhelminth a & $\mathrm{nm}$ & - & - & - & - & - \\
\hline Platyhelminth b & 0.155 & 0.013 & 0.006 & 0.012 & - & - \\
\hline Platyhelminth c & $\mathrm{nm}$ & - & - & - & - & - \\
\hline $\begin{array}{l}\text { Unidentified proto- } \\
\text { zoan cysts }\end{array}$ & 0.010 & 0.008 & 0.004 & 0.008 & 0.008 & 0.005 \\
\hline Mean P/Csp & & 0.243 & 0.023 & 0.008 & 0.015 & 0.010 \\
\hline
\end{tabular}

1972), northeastern Atlantic (Øresland 1986), southwestern Atlantic (Daponte et al. 2008), and the Seto Inland Sea (Ohtsuka et al. 2004) (Table 1). These investigations reported a relatively low diversity of parasite species assemblages. In our study, we found considerably larger numbers of parasite species (33 types of parasites) and in a larger number of chaetognath host species (5 species) than previous time series. Worldwide, parasite diversity is geographically biased. We know disproportionally less about parasites in the tropics than in higher latitudes (Kamiya et al. 2014, Poulin 2001, 2014). Investigations of parasite diversity, as a function of latitudinal zones, show no predictable pattern because different parasite species are not using the hosts to the same degree and because parasite taxonomy is still incomplete (Poulin 2007, Kamiya et al. 2014).
Thus, predicting how many species can exploit a particular host is impossible (Poulin 2007, 2014). The high diversity of parasites observed off the Yucatan Peninsula results from a systematic effort to identify chaetognath hosts and comparing parasitechaetognath assemblages of 2 adjacent but environmentally distinct habitats with pronounced differences in salinity. The relatively high diversity of chaetognaths along the northeastern coast of Quintana Roo is likely a response to a narrow continental shelf $(<6 \mathrm{~km}$ wide) that is affected by strong ocean currents (Merino 1986, Gasca et al. 1996, Athie et al. 2011). This explains why we collected oceanic species on the continental shelf and coral reef (Eukrohnia hamata, Pterosagitta draco, Flaccisagitta enflata, F. hexaptera, Mesosagitta minima, Sagitta bipunctata, and Serratosagitta serratodentata). 


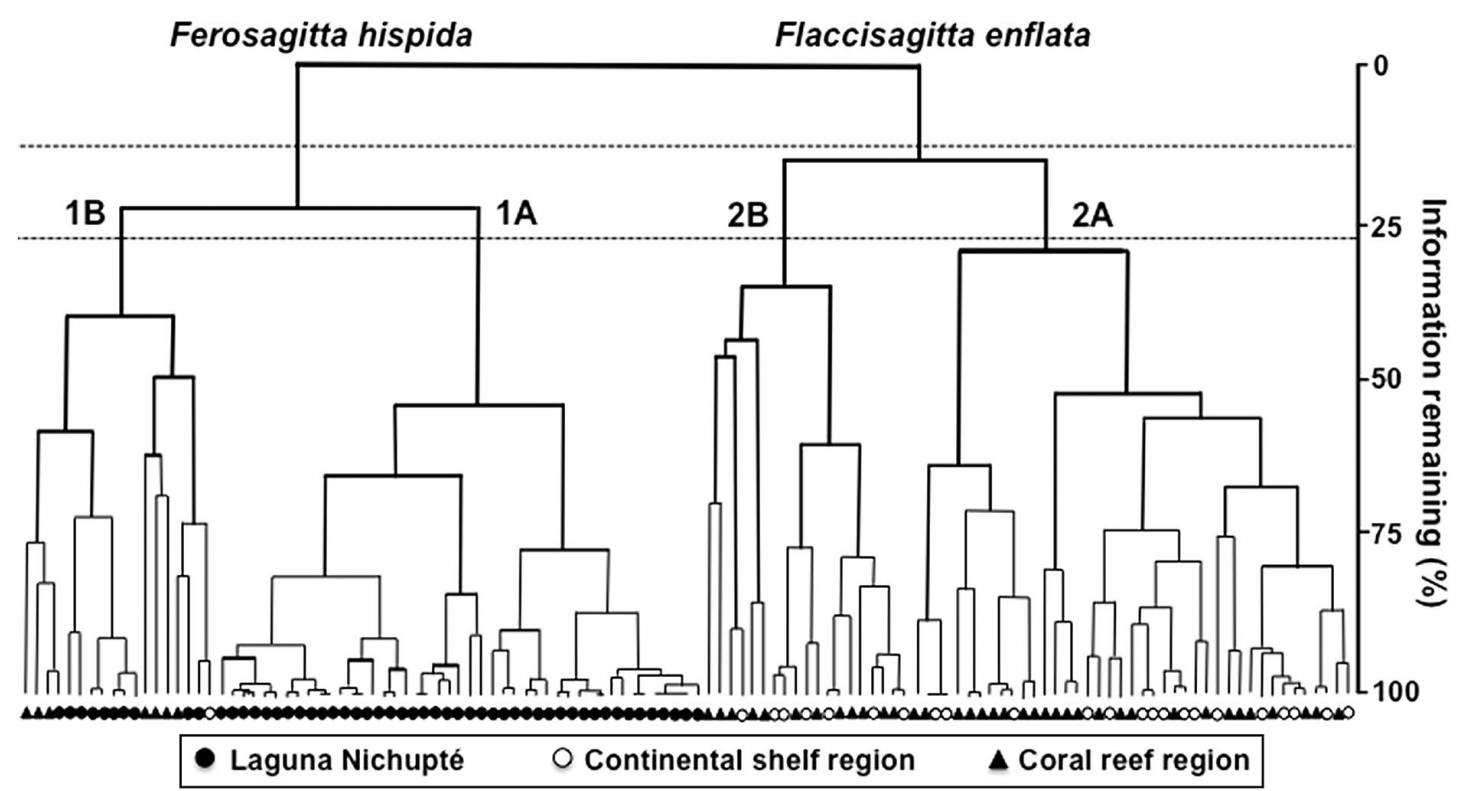

Fig. 6. Cluster analysis of the abundance of parasites and 5 parasitized chaetognath species collected at each station sampled in 2004 and 2005. Four groups were detected: Ferosagitta hispida in the Laguna Nichupté (Group 1A), F. hispida in LN-CS regions (Group 1B), and Flaccisagitta enflata on the continental shelf and coral reefs in 2004 (Group 2A) and 2005 (Group 2B).

Dotted lines indicate the cut offs that define the 2 groups $(12 \%)$ and 4 subgroups $(28 \%)$ of sampling stations

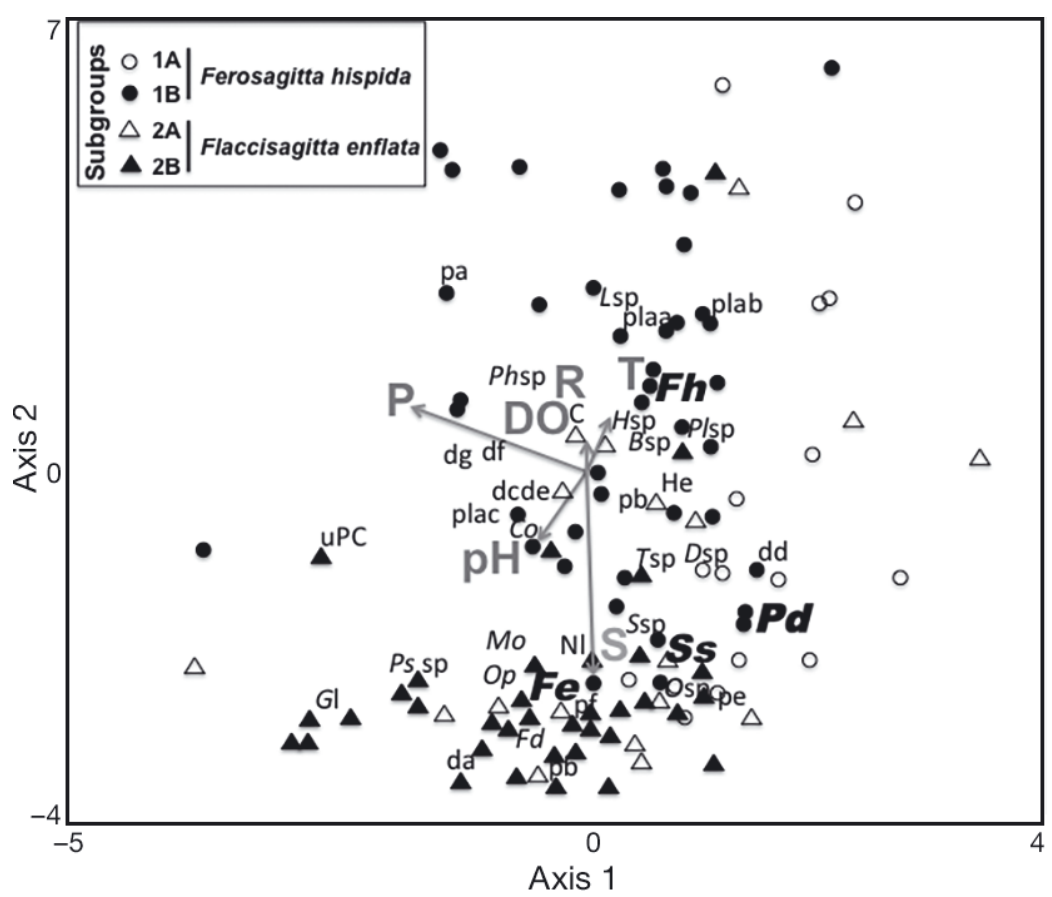

Fig. 7. Canonical correspondence analysis of the relationship between parasitism and groups of stations as a function of dissolved oxygen (DO), prevalence of parasitism $(\mathrm{P}), \mathrm{pH}$, rainfall $(\mathrm{R})$, surface temperature $(\mathrm{T})$, and surface salinity (S). Abbreviations are given in Table 4

Although Krohnitta pacifica, Ferosagitta hispida, Parasagitta helenae, P. friderici, and $P$. tenuis are considered neritic species (Alvariño 1965, McLelland 1989), only F. hispida survive and proliferate in the shallow and low-salinity Laguna Nichupté (Suárez-Morales et al. 1990, Álvarez-Cadena et al. 1996a,b, 2007, 2009, Gasca et al. 1996, Ramírez-Ávila \& Álvarez-Cadena 1999, HernándezFlores 2003). F. hispida is a euryhaline $(20-45)$ and eurythermic $\left(21-29^{\circ} \mathrm{C}\right)$ species inhabiting coastal waters with highly variable seasonal environmental conditions (Suárez-Caabro 1955, Boltovskoy 1981, Álvarez-Cadena et al. 1996b, Liang 2002). Our findings indicate that $F$. hispida is also tolerant of a relatively wide range of DO concentrations (3.25-7.03 $\left.\mathrm{ml} \mathrm{l}^{-1}\right)$. Using growth rate measurements, Reeve (1970) reported that $F$. hispida did not survive if exposed to $>33.5^{\circ} \mathrm{C}$ for $>15 \mathrm{~d}$. Moreover, this species typically reaches maturity under a wide range of salinities (25-40), but cannot mature at a salinity <20 (Reeve 1970). This physiological response suggests that, following hurricanes when salinity drops precipitously, F. hispida reproduction in Laguna Nichupté drops sharply. The first record of parasites in F. hispida was in Biscayne Bay, Florida, USA (Overstreet 1969), and the second in Quintana Roo, Mexico (Gómez del Prado-Rosas et al. 1999b). F. hispida is a small neritic 
species $(<12 \mathrm{~mm} \mathrm{TL})$, making it more difficult to detect parasites than in larger oceanic chaetognaths, such as F. enflata (<25 mm TL) (McLelland 1989); moreover, it has a relatively restricted neritic distribution on both sides of the tropical-equatorial Atlantic Ocean (Alvariño 1965).

Except for F. hispida and F. enflata, all oceanic species were collected at relatively low abundances, reducing the likelihood of being parasitized. One interesting finding is that of the 13 chaetognath species found in our study, only F. hispida, F. enflata, $S$. serratodentata, P. draco, and Sagitta spp. (including several unidentified species) were parasitized. The first 2 species and Sagitta spp. were numerically dominant, thus representing a large available intermediate host reservoir for endoparasites. One new finding is that $P$. draco is a new host of helminths in the Caribbean Sea, while another 3 chaetognath species were previously found parasitized with digeneans, cestodes, and nematodes in other regions of the world (Reimer et al. 1975, Shimazu 1978, Jarling \& Kapp 1985, Øresland 1986, Mazzoni 1986, PierrotBults 1990). Seven chaetognath species have been reported as intermediate or paratenic hosts off the Yucatan Peninsula. F. enflata, F. hispida (Gómez del Prado-Rosas et al. 1999b, 2002, 2005, 2007b), and $S$. serratodentata (Gómez del Prado-Rosas et al. 1999a,b, 2005, 2007b) are the most commonly found hosts in these reports. Less frequently parasitized species are S. bipunctata, $P$. helenae, and P. friderici (Gómez del Prado-Rosas et al. 1999b, 2005). It is not clear why the other 7 species were not infected; likely, it is associated with a density-dependent parasite-host process, feeding habits, or size of parasites and host (Poulin \& Valtonen 2001). Relatively low abundance and frequency of the other chaetognath species and smaller body length may explain why they did not appear to be parasitized. Moravec et al. (1995), Lafferty (1999), and Poulin \& Valtonen (2001) suggested that one of the most important factors influencing the presence of certain parasites is that the host species must have a high population density. This is true for F. hispida, a very abundant species and the only chaetognath found in the lagoon (Álvarez-Cadena et al. 1996a), and for F. enflata, the most abundant species along the continental shelf-coral reefs (Ramírez-Ávila \& Álvarez-Cadena 1999).

We found 12 chaetognath species (plus Sagitta spp.), which represent $71 \%$ of the 17 chaetognath species previously recorded along the eastern Yucatan Peninsula coast (Suárez-Morales et al. 1990, Gasca et al. 1996, Álvarez-Cadena et al. 1996a,b, 2007, Ramírez-Ávila \& Álvarez-Cadena 1999,
Hernández-Flores 2003). The Caribbean Sea and Gulf of Mexico host 24 chaetognath species (McLelland 1989). The most abundant chaetognaths in our study were F. hispida, F. enflata, S. serratodentata, $K$. pacifica, $P$. draco, and $F$. hexaptera, which were also reported by Michel \& Foyo (1976). The prevalence and mean intensity of parasites in our study were considerably higher than those reported in other studies of chaetognaths along the coast of the Yucatan Peninsula (Tables 3 \& 6). Our work was an extremely systematic effort to inspect every specimen collected in all zooplankton samples. Prevalence and abundance found in the Gulf of Mexico and Caribbean Sea was even higher than parasites infecting other zooplankton taxonomic groups, such as jellies, euphausiids, and fish larvae (Table 7). This suggests that chaetognaths are major biomass reservoirs for trophically transmitted parasites in this region (Table 7). Our extensive and systematic sampling and analyzing effort over 2 yr detected more diverse and higher rates of prevalence than any previous studies, which involved shorter, non-systematic sampling periods or serendipitous discoveries of parasites at tropical latitudes. However, these earlier studies provided valuable taxonomic knowledge for identifying helminth parasites in this region.

The most enigmatic and non-helminth type of parasite found in our study were the unidentified protozoan cysts. Weinstein (1972) reported chaetognaths with abnormally flaccid and swollen body when they were infected with Metaphrya sagittae ciliate cysts. Ciliates were dispersed throughout the hemocoel of Parasagitta (low prevalence of $1-2.6 \%$ and low intensity, but considerable increase as chaetognath size increases). M. sagittae parasitizes chaetognath species in 7 other regions (Weinstein 1972, Jarling \& Kapp 1985, Øresland 1986). Ohtsuka et al. (2004) found Vampyrophrya pelagica ciliates swimming in the digestive track of 3 species of chaetognaths. Based on the diversity of cell size and shape along the Yucatan Peninsula, we suspect that multiple unidentified protozoan species infect chaetognaths, but the identification of these protozoans awaits future studies.

Although chaetognaths display extensive daily vertical migrations (up to hundreds of meters), our near-surface sampling method collected chaetognaths in the first $5 \mathrm{~m}$. However, chaetognaths in our area of study should move shorter distances in the water column because the bottom of the lagoon is $<5 \mathrm{~m}$ and that of the continental shelf is $<40 \mathrm{~m}$. Higher densities near the sea floor may increase interaction with benthic and demersal prey and predators. 
Table 6. Canonical correspondence analysis and Pearson and Kendall correlations with ordination axes (123 sampling stations) of chaetognath and parasite species abundance and environmental conditions observed in the Caribbean Sea, Mexico

(2004-2005)

\begin{tabular}{|c|c|c|c|c|c|c|c|c|c|}
\hline \multirow[b]{2}{*}{ Variables } & \multicolumn{3}{|c|}{-Axis 1} & \multicolumn{3}{|c|}{-Axis 2} & \multicolumn{3}{|c|}{-Axis 3} \\
\hline & $\mathrm{r}$ & $r^{2}$ & tau & $\mathrm{r}$ & $r^{2}$ & tau & $\mathrm{r}$ & $r^{2}$ & tau \\
\hline \multicolumn{10}{|l|}{ Chaetognaths } \\
\hline Ferosagitta hispida & 0.228 & 0.052 & 0.346 & -0.251 & 0.063 & -0.360 & -0.155 & 0.024 & -0.111 \\
\hline Flaccisagitta enflata & -0.246 & 0.061 & -0.379 & 0.267 & 0.071 & 0.403 & -0.131 & 0.017 & -0.062 \\
\hline Pterosagitta draco & -0.177 & 0.031 & -0.217 & 0.218 & 0.047 & 0.244 & -0.179 & 0.032 & -0.122 \\
\hline Serratosagitta serratodentata & -0.212 & 0.045 & -0.274 & 0.161 & 0.026 & 0.193 & 0.043 & 0.002 & 0.018 \\
\hline Sagitta spp. & -0.212 & 0.045 & -0.274 & 0.161 & 0.026 & 0.193 & 0.043 & 0.002 & 0.018 \\
\hline \multicolumn{10}{|l|}{ Parasites } \\
\hline Prevalence & 0.218 & 0.047 & 0.086 & 0.266 & 0.071 & 0.218 & -0.082 & 0.007 & -0.106 \\
\hline Parasites (total) & 0.371 & 0.138 & 0.305 & -0.054 & 0.003 & -0.127 & -0.078 & 0.006 & -0.230 \\
\hline Gyrodactylidae larva & -0.023 & 0.001 & 0.010 & 0.134 & 0.018 & 0.123 & -0.160 & 0.026 & -0.119 \\
\hline Cercaria owreae & -0.017 & 0.000 & 0.037 & 0.046 & 0.002 & 0.008 & -0.044 & 0.002 & -0.045 \\
\hline Monilicaecum type & -0.233 & 0.054 & -0.265 & 0.352 & 0.124 & 0.378 & -0.149 & 0.022 & -0.095 \\
\hline Hemiuridae & 0.018 & 0.000 & 0.107 & -0.102 & 0.010 & -0.141 & 0.034 & 0.001 & 0.034 \\
\hline Parahemiurus sp. & 0.219 & 0.048 & 0.202 & -0.055 & 0.003 & -0.063 & -0.209 & 0.044 & -0.189 \\
\hline Lecithochirium sp. & 0.208 & 0.043 & 0.232 & -0.204 & 0.042 & -0.118 & -0.013 & 0.000 & -0.025 \\
\hline Brachyaphallus sp. & 0.026 & 0.001 & 0.061 & -0.063 & 0.004 & -0.151 & 0.187 & 0.035 & 0.051 \\
\hline Paralecithochirium sp. & -0.009 & 0.000 & 0.023 & -0.092 & 0.009 & -0.090 & 0.069 & 0.005 & 0.086 \\
\hline Opisthadena sp. & -0.087 & 0.008 & -0.067 & 0.039 & 0.002 & 0.034 & 0.011 & 0.000 & 0.031 \\
\hline Dinosoma sp. & -0.119 & 0.014 & -0.088 & 0.015 & 0.000 & 0.015 & 0.218 & 0.047 & 0.092 \\
\hline Opechona pyriforme & -0.143 & 0.020 & -0.140 & 0.194 & 0.038 & 0.188 & -0.058 & 0.003 & 0.014 \\
\hline Tergestia sp. & -0.070 & 0.005 & -0.032 & 0.007 & 0.000 & -0.027 & 0.060 & 0.004 & 0.103 \\
\hline Digenea a & -0.076 & 0.006 & -0.075 & 0.111 & 0.012 & 0.115 & -0.047 & 0.002 & -0.067 \\
\hline Digenea b & -0.091 & 0.008 & -0.113 & 0.094 & 0.009 & 0.102 & -0.018 & 0.000 & -0.015 \\
\hline Digenea c & 0.014 & 0.000 & 0.042 & -0.008 & 0.000 & -0.015 & -0.039 & 0.002 & -0.059 \\
\hline Digenea d & -0.041 & 0.002 & -0.013 & -0.001 & 0.000 & -0.010 & 0.056 & 0.003 & 0.073 \\
\hline Digenea e & 0.014 & 0.000 & 0.042 & -0.008 & 0.000 & -0.015 & -0.039 & 0.002 & -0.059 \\
\hline Digenea f & 0.041 & 0.002 & 0.071 & 0.020 & 0.000 & 0.001 & -0.025 & 0.001 & -0.024 \\
\hline Digenea g & 0.287 & 0.082 & 0.080 & 0.035 & 0.001 & 0.085 & -0.017 & 0.000 & -0.115 \\
\hline Sporocyst & 0.307 & 0.094 & 0.170 & 0.020 & 0.000 & -0.029 & -0.007 & 0.000 & -0.036 \\
\hline Plerocercoid a & 0.134 & 0.018 & 0.105 & -0.023 & 0.001 & -0.029 & -0.229 & 0.053 & -0.128 \\
\hline Plerocercoid b & -0.013 & 0.000 & 0.064 & -0.012 & 0.000 & -0.078 & -0.018 & 0.000 & -0.022 \\
\hline Plerocercoid c & 0.013 & 0.000 & 0.040 & 0.049 & 0.002 & 0.029 & -0.024 & 0.001 & -0.027 \\
\hline Plerocercoid d & -0.070 & 0.005 & -0.063 & -0.025 & 0.001 & -0.038 & 0.069 & 0.005 & 0.084 \\
\hline Plerocercoid e & -0.085 & 0.007 & -0.092 & 0.026 & 0.001 & 0.010 & 0.116 & 0.013 & 0.109 \\
\hline Plerocercoid f & -0.067 & 0.004 & -0.056 & 0.073 & 0.005 & 0.061 & -0.049 & 0.002 & -0.071 \\
\hline Nematode larva & -0.066 & 0.004 & -0.053 & 0.095 & 0.009 & 0.082 & 0.015 & 0.000 & 0.033 \\
\hline $\begin{array}{l}\text { Procamallanus } \\
\text { (Spirocamallanus) sp. }\end{array}$ & -0.032 & 0.001 & -0.004 & 0.085 & 0.007 & 0.088 & -0.166 & 0.028 & -0.123 \\
\hline Platyhelminth a & 0.077 & 0.006 & 0.079 & -0.070 & 0.005 & -0.077 & -0.080 & 0.006 & -0.086 \\
\hline Platyhelminth $\mathrm{b}$ & 0.173 & 0.030 & 0.131 & -0.226 & 0.051 & -0.182 & -0.023 & 0.001 & -0.017 \\
\hline Platyhelminth $\mathrm{c}$ & 0.014 & 0.000 & 0.042 & -0.008 & 0.000 & -0.015 & -0.039 & 0.002 & -0.059 \\
\hline Unidentified protozoan cysts & 0.383 & 0.146 & 0.376 & -0.072 & 0.005 & -0.178 & -0.083 & 0.007 & -0.268 \\
\hline \multicolumn{10}{|l|}{ Environmental conditions } \\
\hline Temperature & 0.039 & 0.002 & -0.011 & -0.226 & 0.051 & -0.161 & 0.516 & 0.266 & 0.390 \\
\hline Salinity & -0.936 & 0.876 & -0.704 & 0.684 & 0.468 & 0.421 & 0.380 & 0.145 & 0.308 \\
\hline Oxygen concentration & -0.113 & 0.013 & -0.149 & -0.018 & 0.000 & 0.002 & 0.573 & 0.329 & 0.357 \\
\hline Potential hydrogen & -0.057 & 0.003 & -0.101 & 0.538 & 0.289 & 0.362 & $-0-251$ & -0.063 & -0.210 \\
\hline Rainfall & -0.085 & 0.007 & -0.020 & 0.026 & 0.001 & -0.022 & 0.603 & 0.364 & 0.369 \\
\hline
\end{tabular}

Under the greatly contrasting conditions in the lagoon and continental shelf, where different chaetognath host species numerically dominate, there is likely to be distinct host diversity, including primary (mollusks), intermediate (copepods, fishes), and final hosts (fish, sea birds, and marine mammals), that promotes distinct differences in parasite prevalence and species composition as they transit from the intermediate chaetognath hosts. Distinct parasites seem to find suitable primary, intermediate, and definitive hosts 


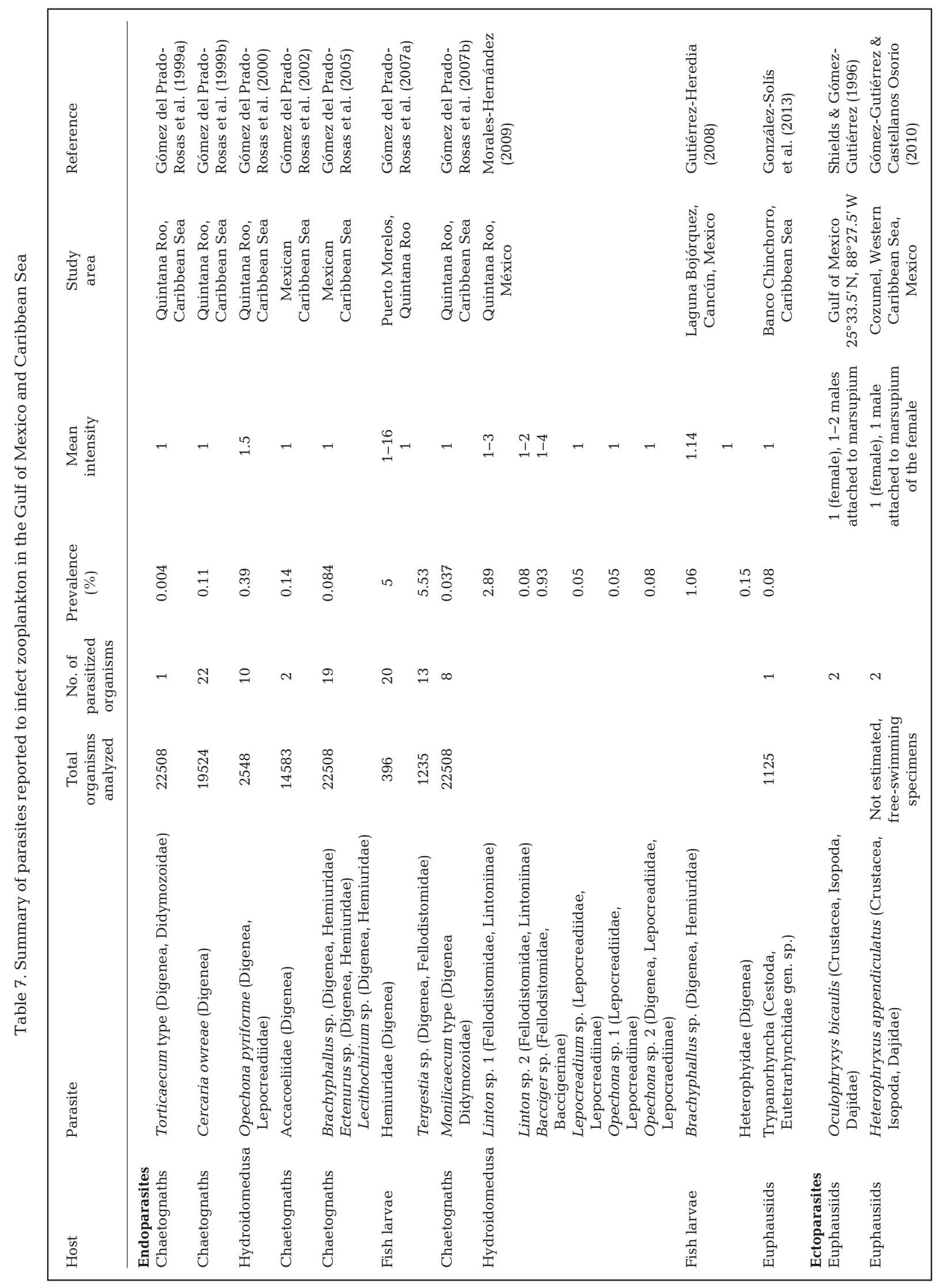


in this shallow lagoon. The Gulf of Mexico and Caribbean Sea contain $>50 \%$ of Mexico's coastal wetlands, nearly $6000 \mathrm{~km}^{2}$ of lagoons, and the most extensive areas of coral reefs in Mesoamerica. These habitats sustain more than 8500 species of marine invertebrates and fishes, 328 species of birds, 29 species of marine mammals, and 5 species of marine turtles (Benitez et al. 2014). High species diversity should also promote a proportionately highly diverse parasitic species assemblage, as observed in the area of study, compared with temperate ecosystems (Table 1). A diverse assemblage of cestode and trematode generalist species parasitizes mollusks (first intermediate hosts) and fish (second intermediate hosts) in the Caribbean Sea (Cake 1976, ArgáezGarcía 2003, Jensen 2009). For example, at least 93 species of cestodes have been reported in the Gulf of Mexico, parasitizing 244 host species (Jensen 2009). Larval cestodes infect invertebrates (Cnidaria, Mollusca, decapod crustaceans), and adult cestodes infect actinopterygians, elasmobranchs, and marine mammals (Mignucci-Giannoni et al. 1998, Jensen 2009). Copepods interact with an assemblage of diverse parasitic species, including bacteria (on the body surface and in the gut), ectoparasites (fungi, diatoms, ellobiopsids, apostomes and suctorian ciliates, and larvae of epicaridean isopods), and endoparasites (dinoflagellates, gregarines, haplosporidians, digeneans, cestodes, nematodes, and acanthocephalans) (Ho \& Perkins 1985, Huys \& Bodin 1997). Most helminth species have complex life cycles that involve intermediate invertebrate hosts that, after being preyed on by predators, complete their life cycle by infecting top predators. Shimazu (1978) reported that chaetognaths are infected with helminth larvae after they prey on copepods, which are frequently the second intermediate host. Ho \& Perkins (1985) argued that almost all metacercariae found in the hemocoel of marine copepods belong to a single family, Hemiuridae, a large family of parasites that invade the esophagus and stomach of fish. Hemiuridae were the most diverse and frequent parasites of chaetognaths in our study area.

In a monthly time series (December 1990-November 1991) carried out at 3 stations in Laguna Nichupté and the adjacent continental shelf, decapod larvae (39\%) and copepods (29\%) were the most abundant and diverse zooplankton taxonomic groups (ÁlvarezCadena \& Segura-Puertas 1997). Those authors reported a total of 47 copepod species, with 14 species in Laguna Nichupté dominated by Acartia tonsa (35-94\% of total copepod abundance in the lagoon) and 42 species on the continental shelf, numerically dominated by Paracalaus quasimodo (21-40\%). These copepods may be frequent prey of chaetognaths in this region, particularly because $A$. tonsa has been reported as an intermediate host of nematodes in other regions (Balbuena et al. 1998). Thus, chaetognaths act as intermediate or paratenic hosts for helminth larvae before they reach the nektonic intermediate or final host, as known for parasites in the family Didymozoidae that infect several fish species (Shimazu 1978, Pierrot-Bults 1990, Gómez del PradoRosas et al. 2007b). Although helminths and other parasites of zooplankton have been studied in the Gulf of Mexico and Caribbean Sea (Table 7), published information describing parasite life cycles is still fragmented. Gómez del Prado-Rosas et al. (2011) recorded metacercariae of the family Hemiuridae, Brachyphallus spp., and Parahemiurus spp., infecting the calanoid copepod Acartia (Odontacartia) lilljeborjii that are frequent prey of chaetognaths. Almeida et al. (2009) observed that some chaetognaths in Brazil were highly infected with Parahemiurus merus that released eggs and hatched inside the coelom of the chaetognath. This was also observed in Parahemiurus spp. of chaetognaths collected in the upper Gulf of California (Lozano-Cobo et al. 2012).

Parasites infecting the chaetognath's head, coelom, gut, and ovaries are similar to those described by Nagasawa (1991). The caudal septa should also be listed as a frequent microsite of infection. We did not find epibionts on chaetognaths. However, we found only 2 types of ectoparasites infesting chaetognaths (monogenean Gyrodactylidae larvae and the unidentified platyhelminth type c). This is the second record of a monogenean infesting a chaetognath since the first monogenean was discovered in 1858 infesting Sagitta germanica (currently known as Parasagitta setosa) (Leuckart \& Pagenstecher 1858). Because we observed a monogenean Gyrodactylidae larval ectoparasite on only one occasion, and these monogeneans supposedly infest fish gills and skin, we propose that this was an accidental infestation. Chaetognaths have a soft skin with epidermal cells that produce mucus (Shinn 1997, Perez et al. 1999). Mucus and soft epidermis seems to be an unfavorable substrate for epibiont organisms, in contrast to infested zooplanktonic crustaceans that possess a hard exoskeleton (Chiavelli et al. 1993, Ohtsuka et al. 2004, 2011, Walkusz \& Rolbiecki 2007, Gómez-Gutiérrez et al. 2010). Thus, we propose the hypothesis that such morphological features may explain why chaetognaths do not have epibionts and have a comparatively lower incidence of ectoparasites than endoparasites. 


\section{Parasite-host size proportion}

Chaetognaths have lower carbon content (mean $34.3 \%$ of dry body weight) than zooplanktonic crustaceans (copepods, euphausiids, mysids), polychaetes, fish larvae (means ranging between 41.7 and $47.6 \%$ ), but higher carbon content than siphonophores and Hydromedusae (means ranging between 10.4 and $16 \%$ ) (Beers 1966). This pattern among taxonomic groups is also true for nitrogen and phosphorus contents (Beers 1966). We propose the hypothesis that parasites of chaetognaths are typically small (overall mean P/Csp $=0.052$ ), perhaps as a parasite adaptation to infect hosts with a relatively small carbon content and with a high proportion of water (Table 5). Even the largest observed parasites (nematode and Procamallanus [Spirocamallanus] sp. larvae) have small P/Csp in comparison with parasites observed on other zooplanktonic organisms. The small P/Csp contrasts with the proportionally large helminth parasites that infect zooplanktonic crustaceans that usually have relatively high carbon content (Huys \& Bodin 1997, Gómez-Gutiérrez et al. 2010, Gregori et al. 2012, 2013). Alves \& Luque (2001) mentioned that helminth larvae typically cause negligible damage to their hosts, unless they are present in large intensities, increasing the P/Csp (or biomass proportion).

\section{Environmental conditions related to chaetognath-parasite associations}

We found highly diverse chaetognath species along the continental shelf and a virtually monospecific dominance by $F$. hispida in the lagoon. The lagoon had a distinctive assemblage of host and parasite species that differed from the assemblages found on coral reefs and the continental shelf. The 2 habitats experience seasonal changes in environmental conditions; chaetognath abundance declines during the rainy season, particularly in the lagoon, where the shallow bottom $(<3 \mathrm{~m})$ causes highly variable temperature, salinity, and oxygen concentration. During the rainy season, particularly during hurricane events, salinity decreases and creates harsh conditions for all chaetognath species, except $F$. hispida. The shallow lagoon has a characteristic low salinity (caused by rainfall and groundwater discharge) and slow flushing time (1.3-1.9 yr) because mixing with the water over the continental shelf requires flowing through 2 shallow $(<4 \mathrm{~m})$ and narrow mouths (<30 m wide) (Merino 1986, Merino et al. 1990, Athie et al. 2011) that favor numerical dominance of the euryhaline $F$. hispida over other chaetognath species that cannot reproduce and maintain stable populations inside the lagoon. Because F. hispida and F. enflata were the most abundant species, they defined the associations of chaetognath and parasite species into 2 distinct habitats. The transitional conditions with numerical dominance of $F$. hispida over F. enflata were previously reported on Yucatan coral reefs (Ramírez-Ávila \& Álvarez-Cadena 1999). The location where $F$. enflata had high abundance and high parasite species richness prevailed in the low temperatures and high salinities typical of the continental shelf (McLelland 1989, Crelier \& Daponte 2004). Suárez-Caabro (1955) reported that $F$. enflata is a eurythermic species inhabiting areas with temperatures ranging from 16 to $32^{\circ} \mathrm{C}$.

As in other reports, our CCA showed that salinity was significantly and positively correlated with high abundance of $F$. enflata, $S$. serratodentata, and $P$. draco, typically where oligotrophic conditions, as well as relatively low primary and secondary production, prevail (Álvarez-Cadena et al. 1996b, RamírezÁvila \& Álvarez-Cadena 1999). Álvarez-Cadena et al. (2007) reported that low abundance of chaetognaths is associated with locations and periods with low DO. The northern coast of Quintana Roo has less coral reef habitat, but the sea floor is mostly white coral sand, where strong currents and wave dynamics are present. At shallow depths, this habitat favors seagrass and macroalgae meadows that decrease seawater DO. The presence of extensive seagrass beds creates a habitat where only F. hispida attain high population densities, decreasing rapidly on the continental shelf and coral reef areas. The lagoon is generally unsuitable for chaetognath species that inhabit the continental shelf.

In summary, we discovered that the most abundant chaetognath species (F. hispida, F. enflata, and Sagitta spp.) and moderately abundant species (S. serratodentata and $P$. draco) are prey with a highly diverse parasitic species assemblage at tropical latitudes. Low chaetognath abundance is likely the most parsimonious explanation why the other 8 species did not show parasitism (relative abundance 0.1$1.5 \%$ ), including $K$. pacifica and $P$. tenuis, which are the fourth $(1.5 \%)$ and sixth $(0.4 \%)$ most abundant chaetognath species in the study area (Table 2). We conclude that parasites have a close association with abundance and species composition of chaetognaths based on seasonal variations and lagoon-coastal habitats, with distinct parasite relative abundances among host species in each habitat. Environmental conditions in Laguna Nichupté are favorable for $F$. 
hispida, but are inhospitable to other oceanic chaetognath species. In this shallow lagoon, with mangroves and seagrass, there may be enhanced benthic interaction of chaetognaths with mollusks (and other primary hosts), which favors higher prevalence of digeneans and cestodes. We conclude that, since infected chaetognaths respond differently to saline environmental conditions, numerically dominant chaetognath species in the contrasting lagoon and continental shelf habitats and their prey also promote distinct parasite species assemblages. Future ecological studies should compare parasitic diversity among distinct chaetognath species from different biogeographic regions (Poulin 2007, 2014, Kamiya et al. 2014), with emphasis on seasonal variability to explore seasonal dynamics of parasites among prey and predators of chaetognaths.

Acknowledgements. We dedicate this study to José Nicolás Álvarez Cadena (1948-2009) for his unconditional support and for making available zooplankton collected under the research programs of the Instituto de Ciencias del Mar y Limnología, Universidad Nacional Autónoma de México at Puerto Morelos, Quintana Roo, Mexico. He provided biological material collected in previous research done by the first and second authors. He was a strong influence on the study of zooplankton and parasitism in Mexico. We thank Alma Rosa Almaral Mendivil for technical help in collecting zooplankton and sorting chaetognaths from zooplankton samples. Funding came from CONACYT CB-2012-15876 and CB-2014-01-236864. H.L.C. was a recipient of a CONACYT grant (A140618), as well as PIFI-IPN (SIP20110012) and BEIFI-IPN (SIP 20140497, 20150113, 20160495) grants. L.S.V. and J.G.G. are COFAA-IPN and EDI-IPN fellows.

\section{LITERATURE CITED}

Almeida FC, Barquete V, Pereira J Jr (2009) Progenetic metacercariae of Parahemiurus merus (Platyhelminthes, Digenea, Hemiuridae) infecting Parasagitta friderici (Chaetognatha) from southern coast Brazil. Atlântica 31: 35-38

Álvarez-Cadena JN, Segura-Puertas L (1997) Zooplankton variability and copepod species assemblages from a tropical coastal lagoon. Gulf Res Rep 9:345-355

Álvarez-Cadena JN, Islas-Landeros ME, Suárez-Morales E (1996a) A preliminary zooplankton survey in a Mexican Caribbean eutrophic coastal lagoon. Bull Mar Sci 58: 694-708

Álvarez-Cadena JN, Suárez-Morales E, McLelland JA (1996b) Observations on an isolated population of Sagitta hispida Conant (Chaetognatha) in a tropical lagoon system of northeast Yucatán (Mexico). Gulf Res Rep 9:197-204

Álvarez-Cadena JN, Ordóñez-López U, Valdés-Lozano D, Almaral-Mendívil AR, Ulicab-Sabido A (2007) Estudio anual del zooplancton: composición, abundancia, biomasa e hidrología del norte de Quintana Roo, Mar Caribe de México. Rev Mex Biodivers 78:421-430

Álvarez-Cadena JN, Almaral-Mendivil AR, Ordóñez-López
U, Uicab-Sabido A (2008) Composición, abundancia y distribución de las especies de quetognatos del litoral norte del Caribe de México. Hidrobiológica 18:37-48

* Álvarez-Cadena JN, Ordóñez-López U, Almaral-Mendivil AR, Uicab-Sabido A (2009) Composition and abundance of zooplankton groups from a coral reef lagoon in Puerto Morelos, Quintana Roo, Mexico, during an annual cycle. Rev Biol Trop 57:647-658

Alvariño A (1965) Chaetognaths. Oceanogr Mar Biol Annu Rev 3:115-195

Alves DR, Luque JL (2001) Community ecology of the metazoan parasites of white croaker, Micropogonias funieri (Osteichthyes: Sciaenidae), from the coastal zone of the State of Rio de Janeiro, Brazil. Mem Inst Oswaldo Cruz 96:145-153

Anderson RC, Chabaud AG, Willmontt S (1974) CIH keys to the nematode parasites of vertebrates. Commonwealth Agricultural Bureaux, Farnham Royal

Argáez-García N (2003) Comunidades de helmintos parásitos intestinales del 'pargo mulato' Lutjanus griseus Linneo, 1758 (Pisces: Lutjanidae) en un ambiente marino y uno estuarino del Estado de Yucatán, México. Licenciatura thesis, Universidad Autónoma de Yucatán, Mérida

Athie G, Candela J, Sheinbaum J, Badan A, Ochoa J (2011) Yucatan current variability through the Cozumel and Yucatan channels. Cienc Mar 37:471-492

* Balbuena JA, Karlsbakk E, Saksvik M, Kvenseth AM, Nylund A (1998) New data on the early development of Hysterothylacium aduncum (Nematoda, Anisakidae). J Parasitol 84:615-617

Beers JR (1966) Studies on the chemical composition of the major zooplankton groups in the Sargasso Sea off Bermuda. Limnol Oceanogr 11:520-528

* Benitez JA, Cerón-Bretón RM, Cerón-Bretón JG, RendónVon-Osten J (2014) The environmental impact of human activities on the Mexican coast of the Gulf of Mexico: review of status and trends. WIT Trans Ecol Environ 181: $37-50$

Boltovskoy D (1981) Atlas del zooplancton del Atlántico, sudoccidental y métodos de trabajo con el zooplancton marino. Publicación Especial de INIDEP, Mar de Plata

Bray RA, Gibson DI, Jones A (2008) Keys to the Trematoda, Vol 3. CAB International and Natural History Museum, London

Bush AO, Lafferty KD, Lotz JM, Shostak AW (1997) Parasitology meets ecology on its own terms: Margolis et al. revisited. J Parasitol 83:575-583

Cake EW (1976) A key to larval cestodes of shallow-water, benthic mollusks of the northern Gulf of Mexico. Proc Helminthol Soc Wash 43:160-171

Chiavelli DA, Mills EL, Threlkeld ST (1993) Host preference, seasonality, and community interactions of zooplankton epibionts. Limnol Oceanogr 38:574-583

Crelier AM, Daponte MC (2004) Chaetognatha of the BrazilMalvinas (Falkland) confluence: distribution and associations. Iheringia Ser Zool 94:403-412

Daponte MC, Gil de Pertierra AA, Palmieri MA, Ostrowski de Nuñez M (2008) Monthly occurrence of parasites of the chaetognath Sagitta friderici off Mar del Plata, Argentina. J Plankton Res 30:567-576

Feigenbaum DL, Maris RC (1984) Feeding in the Chaetognatha. Oceanogr Mar Biol Annu Rev 22:343-392

Field JG, Clarke KR, Warwick RM (1982) A practical strategy for analysing multispecies distribution patterns. Mar Ecol Prog Ser 8:37-52 
Gasca R, Álvarez-Cadena JN, Suárez-Morales E (1996) Chaetognath assemblages in the Mexican Caribbean Sea (1991). Caribb Mar Stud 5:41-50

Gibson DI, Jones A, Bray RA (2002) Keys to the Trematoda, Vol 1. CAB International and Natural History Museum, London

Gómez del Prado-Rosas MC, Álvarez-Cadena JN, SeguraPuertas L, Lamothe-Argumedo R (1999a) First record of Torticaecum sp. (Trematoda: Didymozoidae) in the chaetognath Serratosagitta serratodentata (Krohn, 1853) from Caribbean waters. J Plankton Res 21:1005-1008

Gómez del Prado-Rosas MC, Álvarez-Cadena JN, SeguraPuertas L, Lamothe-Argumedo R (1999b) New records, hosts, and SEM observations of Cercaria owreae (Hutton, 1954) from the Mexican Caribbean Sea. J Helminthol Soc Wash 66:194-197

Gómez del Prado-Rosas MC, Segura-Puertas L, ÁlvarezCadena JN, Lamothe-Argumedo R (2000) Opechona pyriforme metacercaria (Trematoda: Lepocreadidae) in Eirene lactea (Cnidaria: Hydroidomedusae) from a reef lagoon in the Mexican Caribbean Sea. An Inst Biol Univ Nac Auton Mex Ser Zool 7:1-6

Kómez del Prado-Rosas MC, Álvarez-Cadena JN, SeguraPuertas L, Lamothe-Argumedo R (2002) An accacoeliid metacercaria parasitizing the arrow worm Flaccisagitta enflata (Grassi, 1881) from the Mexican Caribbean Sea. Comp Parasitol 69:108-111

Gómez del Prado-Rosas MC, Álvarez-Cadena JN, SeguraPuertas L, Lamothe-Argumedo R (2005) Hemiurid metacercariae (Trematoda) in chaetognaths from the Mexican Caribbean Sea. Comp Parasitol 72:230-233

Gómez del Prado-Rosas MC, Álvarez-Cadena JN, LamotheArgumedo R, Ordoñez-López U, Almaral-Mendívil AR (2007a) Larvas de peces parasitadas por metacercarias de Hemiuridae y Fellodistomidae (Trematoda) en la laguna arrecifal de Puerto Morelos, Quintana Roo, México. Hidrobiológica 17:233-239

Gómez del Prado-Rosas MC, Álvarez-Cadena JN, SeguraPuertas L, Lamothe-Argumedo R (2007b) Didymozoid trematode Monilicaecum type in chaetognaths from the Mexican Caribbean Sea. Rev Mex Biodivers 78:483-487

Gómez del Prado-Rosas MC, Valles-Vega I, Lozano-Cobo H, Hernández-Trujillo S (2011) Metacercarias de hemiúridos en copépodos de la Ensenada de La Paz, Baja California Sur, México. Neotrop Helminthol 5:125-137

Kómez-Gutiérrez J, Castellanos-Osorio I (2010) Heterophryxus appendiculatus G.O. Sars, 1885 (Isopoda: Dajidae) extension range in the northeast Pacific and Caribbean Sea (Mexico) that indicates inter-ocean zoogeographic distribution. Crustaceana 83:1221-1230

*Gómez-Gutiérrez J, Robinson CJ, Kawaguchi S, Nicol S (2010) Parasite diversity of Nyctiphanes simplex and Nematoscelis difficilis (Crustacea: Euphausiacea) along the northwestern coast of Mexico. Dis Aquat Org 88:249-266

* González-Solís D, Castellanos-Osorio I, Beverdige I (2013) Larval trypanorhynch (Cestoda) infecting Euphausia americana (Euphausiacea) collected in the Mexican Caribbean Sea. Rev Mex Biodivers 84:664-667

Gregori M, Aznar FJ, Abollo E, Roura A, González AF, Pascual S (2012) Nyctiphanes couchii as intermediate host for the acanthocephalan Bolbosoma balaenae in temperate waters of the NE Atlantic. Dis Aquat Org 99:37-47

Gregori M, Aznar FJ, Abollo E, Roura A, González AF, Pascual S (2013) Nyctiphanes couchii as intermediate host for Rhadinorhynchus sp. (Acanthocephala, Echinorhyn- chidae) from NW Iberian Peninsula waters. Dis Aquat Org 105:9-20

Gutiérrez-Heredia L (2008) Helmintofauna en larvas de peces de la familia Gobiidae de La Laguna Bojórquez, Cancún, Quintana Roo, México. BSc thesis, Universidad Autónoma de Baja California Sur, La Paz

Hernández-Flores RM (2003) Report on collection of chaetognaths from Banco Chinchorro, Mexican Caribbean Sea. Bull Mar Sci 73:123-131

Ho J, Perkins PS (1985) Symbionts of marine Copepoda: an overview. Bull Mar Sci 37:586-598

*Huys R, Bodin P (1997) First record of Acanthocephala in marine copepods. Ophelia 46:217-231

Jarling C, Kapp H (1985) Infestation of Atlantic chaetognaths with helminths and ciliates. Dis Aquat Org 1:23-28

Jensen K (2009) Cestoda (Platyhelminthes) of the Gulf of Mexico. In: Felder DL, Camp DK (eds) Gulf of Mexico origins, waters, and biota. Biodiversity. Texas A\&M University Press, College Station, TX, p 487-522

Jones A, Bray RA, Gibson DI (2005) Keys to the Trematoda, Vol 2. CAB International and Natural History Museum, London

Kamiya T, O'Dwyer K, Nakagawa S, Poulin R (2014) What determines species richness of parasitic organisms? A meta-analysis across animal, plant and fungal hosts. Biol Rev Camb Philos Soc 89:123-134

Khalil LF, Jones A, Bray RA (1994) Keys to the cestode parasites of vertebrates. CAB International and Natural History Museum, London

Kulachkova VG (1972) Helminths of Sagitta elegans Verrill from the White Sea. Parazitologiia 6:297-304

* Lafferty KD (1999) The evolution of trophic transmission. Parasitol Today 15:111-115

Leuckart R, Pagenstecher A (1858) Untersuchungen über niedere Seethiere. Archiv für Anatomie und Physiologie, Leipzig

Liang TH (2002) Chaetognath seasonality and distribution at surface layers off Ubatuba, south Brazil bight coastal waters. Oceánides 17:103-111

Lozano-Cobo H, Gómez del Prado-Rosas MC, Cota-Meza MS, Pacheco-Chávez M, Sánchez-Velasco L (2012) Helmintos parásitos en quetognatos en el Alto Golfo de California, México. The Biologist 10(Suppl 2):32

Lozano-Cobo H, Gómez-Gutiérrez J, Franco-Gordo MC, Gómez del Prado-Rosas MC (2017) Discovery of Acanthocephala parasitizing Chaetognatha. Acta Parasitol 62: 401-411

Mazzoni HE (1986) Chaetognaths infested with larvae of Contracaecum sp. (Nematoda, Anisakidae) in the Argentine Sea. Physis Secc A 44:8-20

McCune B, Grace J, Urban D (2002) Analysis of ecological communities. MjM Software Design. Gleneden Beach, OR

McLelland JA (1989) An illustrated key to the Chaetognatha of the northern Gulf of Mexico with notes on their distribution. Gulf Res Rep 8:145-172

Merino IM (1986) Aspectos de la circulación costera superficial del Caribe Mexicano con base en observaciones utilizando tarjetas de deriva. An Inst Cienc Mar Limnol Univ Nac Auton Mex 13:31-46

* Merino M, Czitrom S, Jordán E, Martin E, Thomé P, Moreno O (1990) Hydrology and rain flushing of the Nichupté lagoon system, Cancún, Mexico. Estuar Coast Shelf Sci 30:223-237

Michel HB, Foyo M (1976) Caribbean zooplankton. I. Siphonophora, Heteropoda, Copepoda, Euphausiacea, 
Chaetognatha and Salpidae. Office of Naval Research, US Dept. Navy, Washington, DC

Mignucci-Giannoni AA, Hoberg EP, Siegel-Causey D, Williams EH Jr (1998) Metazoan parasites and other symbionts of cetaceans in the Caribbean. J Parasitol 84: 939-946

Morales-Hernández MY (2009) Estructura espacial de los tremátodos parásitos de la hidromedusa Clytia folleata (McCrady, 1859) en la zona costera del norte de Quintana Roo. MSc thesis, Universidad Nacional Autónoma de México, Mexico City

Moravec F, Mendoza-Franco E, Vargas-Vázquez J, VivasRodríguez C (1995) Studies on the development of Procamallanus (Spirocamallanus) rebecae (Nematoda: Camallanidae), a parasite of cichlid fishes in Mexico. Folia Parasitol 42:281-292

Nagasawa S (1991) Parasitism and diseases in Chaetognaths. In: Bone Q, Kapp H, Pierrot-Bults AC (eds) The biology of chaetognaths. Oxford Science Publications, New York, NY, p 76-168

Nagasawa S, Nemoto T (1984) X-diseases in the chaetognath Sagitta crassa. Helgol Meeresunters 37:139-148

\% Ohtsuka S, Hora M, Suzaki T, Arikawa M, Omura G, Yamada K (2004) Morphology and host-specificity of the apostome ciliate Vampyrophrya pelagica infecting pelagic copepods in the Seto Inland Sea, Japan. Mar Ecol Prog Ser 282:129-142

Ohtsuka S, Horiguchi T, Hanamura Y, Yamaguchi A and others (2011) Symbiosis of planktonic copepods and mysids with epibionts and parasites in the north Pacific: diversity and interactions. In: Asakura A (ed) New frontiers in crustacean biology. Proceedings of the TCS Summer Meeting, Tokyo, p 1-14

Øresland V (1986) Parasites of the chaetognath Sagitta setosa in the western English Channel. Mar Biol 92:87-91

* Øresland V, Bray RA (2005) Parasites and headless chaetognaths in the Indian Ocean. Mar Biol 147:725-734

Overstreet RM (1969) Digenetic trematodes of marine teleost fishes from Biscayne Bay, Florida. Tulane Stud Zool Bot 15:119-175

Pearre S Jr (1976) Gigantism and partial parasitism castration of Chaetognatha infected with larval trematodes. J Mar Biol Assoc UK 56:503-513

* Pearre S Jr (1979) Niche modification in Chaetognatha infected with larval trematodes (Digenea). Int Rev Gesamten Hydrobiol 64:193-206

* Perez Y, Arnaud J, Brunet M, Casanova JP, Mazza J (1999) Morphological study of the gut in Sagitta setosa, S. serratodentata and $S$. pacifica (Chaetognatha). Functional implications in digestive processes. J Mar Biol Assoc UK 79:1097-1109

Pierrot-Bults AC (1990) Diseases of Chaetognatha. In: Kinne O (ed) Diseases of marine animals, Vol III. Biologische Anstalt Helgoland, Hamburg, p 425-437

Poulin R (2001) Interactions between species and the structure of helminth communities. Parasitology 122:S3-S11

Poulin R (2007) Are there general laws in parasite ecology? Parasitology 134:763-776

Poulin R (2014) Parasite biodiversity revisited: frontiers and constraints. Int J Parasitol 44:581-589

Poulin R, Valtonen ET (2001) Interspecific associations among

Editorial responsibility: Sven Klimpel,

Frankfurt, Germany larval helminths in fish. Int J Parasitol 31:1589-1596

Ramírez-Ávila Y, Álvarez-Cadena JN (1999) Chaetognath species composition from a coral reef lagoon in the Mexican Caribbean Sea. Rev Biol Trop 47:157-163

Reeve MR (1970) The biology of Chaetognatha. 1. Quantitative aspects of growth and reproduction in Sagitta hispida. In: Steele JH (ed) Marine food chains. Oliver and Boyd, Edinburgh, p 168-192

Reimer LW, Hnatiuk S, Rochner J (1975) Metacercarien in Planktontieren des mittleren Atlantik. Wiss Z pädagog Hochsch Güstrow 2:239-258

Salgado-Maldonado G (1979) Procedimientos y técnicas generales empleados en los estudios helmintológicos. Laboratorio de Helmintología, Oficina de Sanidad, Nutrición y Genética, Dirección General de Acuacultura, Departamento de Pesca, Mexico City

Santhakumari V (1992) Diseases of chaetognaths from the Arabian Sea. J Mar Biol Assoc India 34:279-281

* Shields JD, Gómez-Gutiérrez J (1996) Oculophryxus bicaulis a new genus and species of dajid isopod parasitic on the euphausiid Stylocheiron affine Hansen. Int J Parasitol 26: 261-268

Shimazu T (1978) Some helminth parasites of the Chaetognatha from Suruga Bay, central Japan. Bull Natl Sci Museum Tokyo A Zool 4:105-116

Shinn GL (1997) Chaetognatha. In: FW Harrison (ed) Microscopic anatomy of invertebrates. Vol 15: Hemichordata, Chaetognatha and the invertebrate chordates. WileyLiss, New York, NY, p 103-220

Smith P, Richardson S (1977) Standard techniques for pelagic fish egg and larva surveys. FAO Fish Tech Pap 175:1-107

Suárez-Caabro JA (1955) Quetognatos de los mares cubanos. Mem Soc Cub Hist Nat 22:125-180

Suárez-Morales E, Hernández RM, Gasca-Serrano R (1990) Quetognatos (Chaetognatha) de la Bahía de la Ascensión, Reserva de la Bahía de Sian Ka'an, Quintana Roo, México. In: Navarro D, Robinson JG (eds) Diversidad biológica de la Reserva de la Biosfera de Sian Ka'an, Quintana Roo, México. Centro de Investigaciones de Quintana Roo, The Program for Studies in Tropical Conservation, University of Florida, Gainesville, FL, p 137-146

Ter Braak CJF (1986) Canonical correspondence analysis: a new eigenvector technique for multivariate direct gradient analysis. Ecology 67:1167-1179

*Villate F (1991) Annual cycle of zooplankton community in the Abra Harbour Bay of Biscay: abundance, composition and size spectra. J Plankton Res 13:691-706

Walkusz W, Rolbiecki L (2007) Epibionts (Parcineta) and parasites (Ellobiopsis) on copepods from Spitsbergen (Kongsfjorden area). Ocean 49:369-380

Weinstein M (1972) Studies on the relationship between Sagitta elegans Verrill and its endoparasites in the southwestern Gulf of St. Lawrence. PhD thesis, McGill University, Montreal

Yamaguti S (1959) Systema Helminthum. The cestodes of vertebrates, Vol II. Interscience Publishers, New York, NY

Yamaguti S (1961) Systema Helminthum. The nematodes of vertebrates, Vol III, Part I. Interscience Publishers, New York, NY

Yamaguti S (1971) Synopsis of digenetic trematodes of vertebrates, Parts I, II. Keigaku Publishing, Tokyo

Submitted: December 1, 2016; Accepted: January 27, 2017

Proofs received from author(s): March 11, 2017 